\title{
O SISTEMA DE CAPACIDADE DE USO DA TERRA COMO INSTRUMENTO PARA ANÁLISE DE AREA RURAL DEGRADADA
}

\author{
Felipe Augusto Scudeller Zanatta \\ Mestre em Geografia - Organização do Espaço pelo Instituto de Geociências e Ciências Exatas \\ Professor efetivo do Governo do Estado de São Paulo \\ Universidade Estadual Paulista Júlio de Mesquita Filho - UNESP \\ felipeasz@hotmail.com \\ Cenira Maria Lupinacci \\ Doutorado em Geociências e Meio Ambiente \\ Professora Adjunto da Universidade Estadual Paulista - Júlio de Mesquita Filho \\ cenira@rc.unesp.br \\ Marcos Norberto Boin \\ Doutorado em Geociências e Meio Ambiente \\ Universidade Estadual Paulista Júlio de Mesquita Filho - UNESP \\ boinmar@hotmail.com
}

\begin{abstract}
RESUMO
Neste trabalho avalia-se o sistema de capacidade de uso da terra como instrumento para análise de área rural degradada no Oeste Paulista. Para tanto, como objeto de estudo selecionou-se um conjunto de subbacias do ribeirão Areia Dourada, localizadas no Município de Marabá Paulista (SP), as quais se encontram totalmente antropizadas para uso agrícola, restando da mata nativa origináriaem menos de $1 \%$ de toda área. Nessas subbacias, seguindo os procedimentos apresentados por Lepsch et al. (1983), foram mapeadas os declives, as características pedológicas (profundidade, textura e permeabilidade), as formas erosivas lineares (sulco, ravina e voçoroca), e a partir desses mapeamentos elaborou-se a carta de capacidade de uso das terras. Avaliou-se esse zoneamentoda capacidade de uso a partir da dinâmica erosiva e do uso e cobertura superficial da terra, de maneira a identificar suas limitações e potencialidades. Como resultado, constatou-se que apenas no limite de cada propriedade privada não se faz possível o entendimento sistêmico da problemática erosiva, limitando o zoneamento à localização das formas, quando se faz necessário considerar a conectividade entre os processosnos distintos níveis topográficos, bem como a necessidade de avaliar outros elementos, como geologia e formas de relevo, para melhor adequação do zoneamentoàs características e problemática do universo estudado.
\end{abstract}

Palavras-chave: Problemática erosiva. Erosão linear. Capacidade de uso. Adaptação metodológica. Zoneamento agrícola.

\section{THE LAND USE CAPACITY SYSTEM AS AN INSTRUMENT FOR THE ANALYSIS OF DEGRADED RURAL AREA}

\begin{abstract}
This paper evaluates the land use capacity system as an instrument for the analysis of degraded rural areas in the west of São Paulo state. We selected a set of sub-basins of the AreiaDourada stream, located in Marabá Paulista city (SP), which are totally anthropized for agricultural use, remaining from the original native forest less than $1 \%$ of whole area. In these sub-basins, following the procedures presented by Lepsch et al. (1983), we mapped the slopes, the pedological characteristics (depth, texture and permeability), the linear erosive forms (rill, ravine and gully), and from these mappings the land use capacity map was elaborated. This zoning of the capacity of use was evaluated from the erosive dynamics and the use and superficial surface cover of the land, in order to identify its limitations and potentialities. As a result, we verified that, in the limits of private property, the systemic understanding of the erosive problem is not possible, limiting the zoning to the location of the forms, when it is necessary to consider the connectivity between the processes in the different topographic levels, as well as the necessity to evaluate other elements, such as geology and relief forms, to better adapt the zoning to the characteristics and problems of the studied universe.
\end{abstract}

Keywords: Erosive problem. Linear erosion. Capacity of use. Methodological adaptation. Agricultural zoning.

\begin{tabular}{llllll}
\hline Caminhos de Geografia & Uberlândia & v. 20, n. 72 & Dez/2019 & p. 55-77 & Página 55
\end{tabular}




\title{
LE SYSTÈME DE CAPACITÉ D'UTILISATION DE LA TERRE EN TANT QU'INSTRUMENT D'ANALYSE DE LA ZONE RURALE DÉGRADÉE
}

\begin{abstract}
RÉSUMÉ
Dans ce travail, le système de capacité d'utilisation de la terre en tant qu'instrument d'analyse de la zone rurale dégradée dans l'ouest de São Paulo est évalué. Pour cela, on a sélectionné comme objet d'étude un ensemble de sous-bassins du ruisseau Areia Dourada, situé dans la municipalité de Marabá Paulista (SP), qui sont totalement anthropisés pour l'utilisation de l'agriculture, en restant de la forêt primaire moins de $1 \%$ de la zone entière.Dans ces sous-bassins, en suivant les procédures présentés par Lepsch et al. (1983), les pentes, les caractéristiques pédologiques (profondeur, texture et perméabilité), les formes linéaires d'érosion (sillon, ravine et lavaka) ont été cartographiées et, à partir de ces cartographies, la carte de capacité d'utilisation des terres a été élaborée.Ce zonage de la capacité d'utilisation a été évalué à partir de la dynamique érosive et de l'utilisation et couverture de la surface de la terre, afin d'identifier ses limites et potentialités.En conséquence, il a été vérifié que dans l'échelle de la propriété privée la compréhension systémique du problème érosif n'est pas possible, ce que limite le zonage à l'emplacement des formes quand il est nécessaire de considérer la connectivité entre les processus aux différents niveaux topographiques, ainsi que la nécessité d'évaluer d'autres éléments tels que la géologie et les formes de reliefs, pour mieux adapter le zonage aux caractéristiques et aux problèmes de l'univers étudié.
\end{abstract}

Mots-clés: Problématique d'érosion. Érosion linéaire. Capacité d'utilisation. Aaptation méthodologique. Zonage agricole.

\section{INTRODUÇÃO}

As transformações ambientais pelas distintas atividades humanas suscitaram preocupações em relação à exploração dos recursos naturais e à poluição, de modo a direcionarem estudos sobre os limites do desenvolvimento em ritmo industrial. Segundo Santos (2004), tais questionamentos ganharam maiores proporções a partir da década de 1950, em que a World Conservation Union/International Union Conservation Nature apresentou o conceito de desenvolvimento sustentável.

A partir da década de 1970, com as ideias mais consolidadas sobre a necessidade de repensar a questão desenvolvimentista junto à proteção, preservação e conservação dos recursos naturais, na Conferência das Nações Unidades sobre Meio Ambiente Humano, em Estocolomo (1972), criou-se o Programa das Nações Unidas para o Meio Ambiente (PNUMA), a partir do qual foram assinados distintos acordos mundiais e desenvolveram-se políticas ambientais em diversos países (SANTOS, 2004).Lane (2010) ao avaliar metodologias para o estabelecimento da capacidade de carga e de suporte ao uso da terra, destaca que desde 1972, com o advento do Clube de Roma, tem-se a criação de metodologias sistêmicas que visam conhecer os limites sustentáveis de estabelecimento humano das regiões.

No Brasil, esse movimento aparece de maneira mais efetiva em 1981, período de transição da ditadura militar para democracia no país, com a criação da Política Nacional de Meio Ambiente (PNMA) (Lei Federal № 6938 de 1981), em que se define legalmente meio ambiente como "conjunto de condições, leis, influências e interações de ordem, física, química e biológica, que permita, abriga e rege a vida em todas suas formas" (BRASIL, 1981, Art. $2^{\circ}$, Inciso II), considerado "patrimônio público a ser necessariamente assegurado e protegido, tendo em vista o uso coletivo" (Art. $2^{\circ}$, Inciso II).

Posteriormente, a Constituição Federal de 1988, como pacto e marco democrático do país, dedica o Capítulo VI à temática, reforçando o direito ao meio ambiente ecologicamente equilibrado, estabelecido como "essencial à sadia qualidade de vida, cabendo a todos, estado e sociedade civil, o dever de defende-lo e preserva-lo" (Art. 225), mesmo quando do uso privado dos recursos naturais.

Em 2002, através do Decreto N.- 4297 estabeleceram-se os critérios mínimos para a elaboração do Zoneamento Ecológico Econômico, considerado como instrumento de organização do território, com "medidas e padrões de proteções ambiental destinados a assegurar a qualidade ambiental, recursos hídricos, conservação da biodiversidade, garantindo o desenvolvimento sustentável e a melhoria das condições de vida da população" (Art.2\%), distribuindo as atividades econômicas junto da importância ecológica, das limitações e das fragilidades dos ecossistemas.

A elaboração do Zoneamento Ecológico Econômico compete as diversas esferas político-administrativas. À União, incumbe a elaboração do zoneamento nacional e dos zoneamentos regionais, aos estados 0

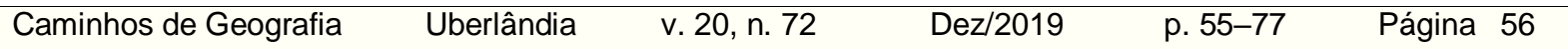


zoneamento estadual, enquanto aos municípios o desenvolvimento do plano diretor, seguindo os zoneamentos de ordem superior. O prazo para elaboração e aprovação desses zoneamentos ficou estabelecido a partir do Código Florestal de 2012 (Lei № 12651/12), com cinco anos para os zoneamentos em nível estadual, segundo metodologia unificada e estabelecida.

Passada uma década e meia da promulgação da Lei N.@4297/2002 e do Zoneamento Ecológico Econômico como instrumento de ordenamento dos usos dos recursos naturais, e do encerramento do prazo de cinco anos para apresentação e aprovação estadual dos zoneamentos (Lei 12.651/2012), no estado de São Paulo tal projeto ainda se encontra em fase de elaboração dos "estudos que subsidiarão os processos de implementação do Zoneamento Ecológico-Econômico" (GOVERNO DO ESTADO DE SÃO PAULO, 2018).

Embora ainda não se tenha um zoneamento consolidado, diversos estudos apresentam propostas para levantar o uso adequado dos recursos naturais. Dentre os quais, para as áreas agrícolas, Lepsch et al. (1983), com base no sistema de capacidade de uso desenvolvido nos Estados Unidos, apresentaram uma classificação técnica para zoneamento do uso da terra, através da síntese de diversas características dos terrenos, "[...] visando à obtenção de classes homogêneas de terras, em termos do propósito de definir sua máxima capacidade de uso sem risco de degradação do solo, especialmente no que diz respeito à erosão acelerada". (LEPSCH et. al, 1983, p.18).

$\mathrm{Na}$ referida metodologia, os autores utilizaram do termo "terra" no intuito de não considerar apenas os solos, mas a localização, o relevo, a vegetação, os tipos e grau de erosão, características climáticas e suprimento de água, infraestrutura e as condições socioeconômicas. A partir de determinadas características, nos limites da propriedade privada, identifica-se a capacidade de uso da terra, sua adaptabilidade a cultivos anuais, perenes, pastagem, silvicultura, reflorestamento ou vida silvestre, sem que proporcionem no desgaste excessivo e no empobrecimento dos solos.

Neste artigo, apresenta-se uma adaptação metodológica da proposta de Lepsch et al. (1983) a fim de avaliar a capacidade de uso das terras em um conjunto de subbacias do ribeirão Areia Dourada, localizadas no município de Marabá Paulista, a W no estado de São Paulo (Figura 1).

Figura 1 - Localização das subbacias do ribeirão Areia Dourada, Marabá Paulista (SP).

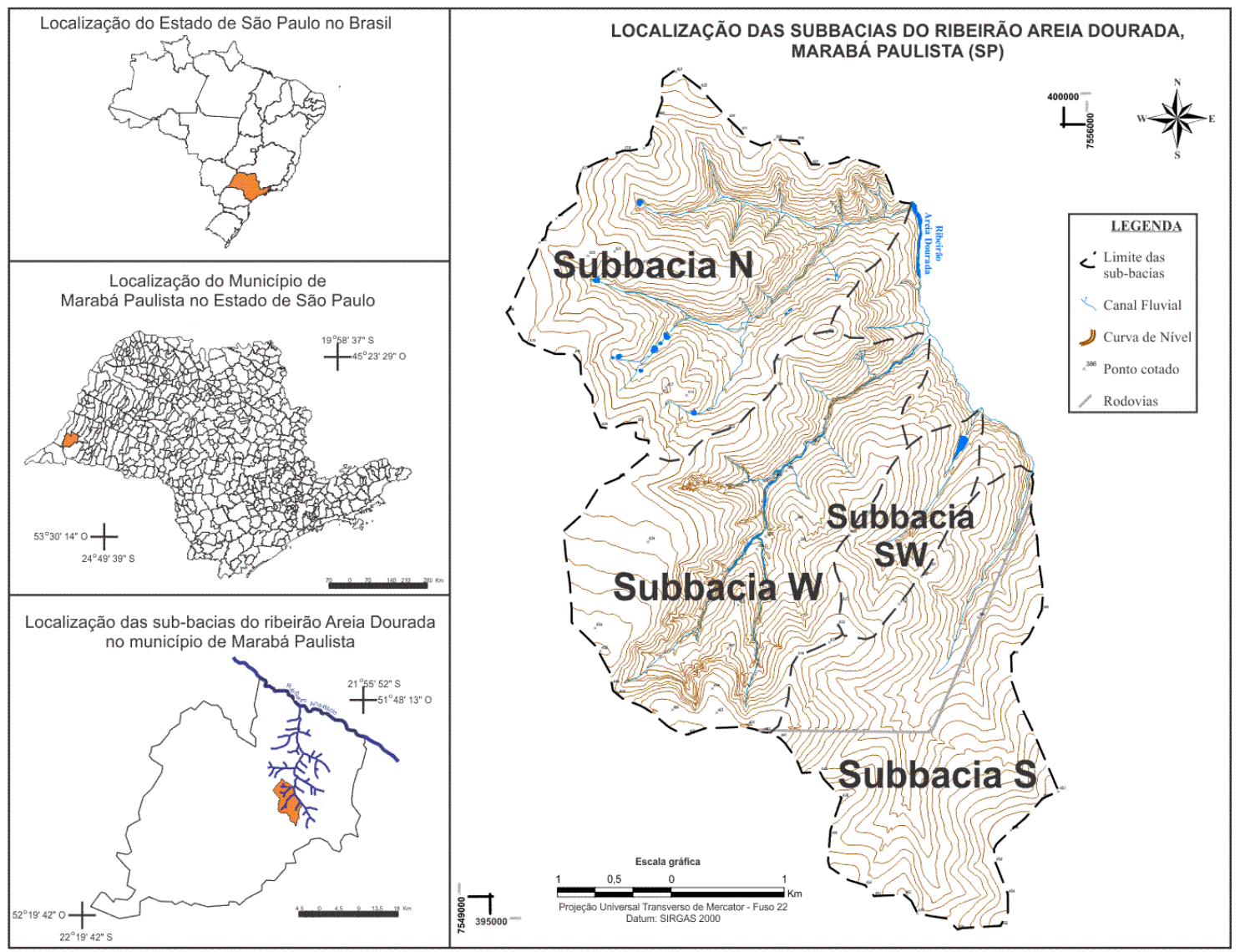


A área objeto deste estudo apresenta uma intensa atividade erosiva presente. De acordo com Instituto de Pesquisas Tecnológicas (IPT, 2012), no município de Marabá Paulista registraram-se 371 formas erosivas, sendo o segundo município mais problemático da Unidade de Gerenciamento de Recursos Hídricos Pontal do Paranapanema (UGRHI-22).

Tal problemática tem como elemento intensificador o uso inadequado das terras desde o início do processo de ocupação do Oeste Paulista, na qual encontra-se a área estudada, datado do final do séc. XIX e início do séc. XX. Este processo, de acordo com Monbeig (1984) e Ferrari Leite (1999), caracterizou-se pela devastação das matas nativas, o genocídio contra os povos que habitavam a região, a ilegal demarcação das propriedades por latifundiários, com processos de grilagem de terra, e o uso contínuo e indiscriminado dos terrenos para atividades agrícolas, base da economia regional. Esta forma de uso, ainda, faz-se sobre condições físicas nada favoráveis ao uso contínuo e generalizado para agropecuária.

Na região, de substrato rochoso derivado de Formações areníticas do Grupo Bauru (IPT 1994, BOIN, 2000; STEIN, 199) o relevo de colinas extensas e suavizadas (AB'SÁBER, 1969), modeladas nos sedimentos do referido Grupo, apresenta setores com declives acentuados, em situações que se tem o contato de diferentes Fácies da Formação Adamantina. A distinta resistência dos materiais das Fácies, de matrizes arenosas sobre silto-argilosas, proporcionam em setores com rupturas topográficas, por vezes com afloramento de água. Os declives acentuados também incidem na direção de fraturas no bloco, onde os canais fluviais se encaixam nas falhas (STEIN, 1993; ZANATTA, CUNHA e BOIN, 2017).

Os solos, derivados de Formações areníticas, apresentam grande concentração de areia, em composição que chega a mais de $90 \%$ das frações granulométricas, e consequente baixa agregação destas. A incidência das classes de solos apresenta relação direta com o declive dos terrenos, de modo a verificarse: Latossolos em terrenos pouco declivosos, de $2+10 \%$, nas vertentes extensas e suavizadas e nos topos; Argissolos nas vertentes de declives de $5 \vdash 15 \%$; e, a jusante de rupturas topográficas abruptas, com declives de $15 \vdash>47 \%$ ocorre Neossolo Litólico ou solos subordinados ao hidromorfismo, este quando da presença de afloramentos de água (CARVALHO et al., 1997; ZANATTA, 2018).

No geral, os solos da região são altamente suscetíveis ao depauperamento quando exposto a ação das chuvas, condicionadas a regime hídrico tropical, em que se tem, nos períodos chuvosos da primavera e verão, um descarregamento de grande volume e intensidade de aguaceiros, que chegam a um impacto de $3.500 \mathrm{MJ} \times \mathrm{mm} \mathrm{x} \mathrm{h}^{-1} \times \mathrm{ha}^{-1}$ (BOIN, 2000). Tais chuvas, por vezes, encontram um ambiente que passou por grandes períodos de estiagem, entre o outono e inverno, de modo que em alguns municípios da região, como Marabá Paulista, passam-se até três meses sem chuvas. Essa sazonalidade das secas e chuvas proporcionam em grande potencial erosivo, principalmente pela fragilidade natural da área, a exposição dos solos e o uso indiscriminado destes.

Portanto, a escolha da proposta metodológica de Lepsch et al. (1983), justifica-se por ter como objetivo a elaboração de um zoneamento da capacidade de uso das terras para áreas agrícolas, uma vez que as sub bacias do ribeirão Areia Dourada, Marabá Paulista (SP) tem na totalidade de seus terrenos usos voltados à atividade agrícola, em um cenário que nitidamente, devido a intensa problemática erosiva, carece deste tipo de levantamento.

Assim, com base na referida metodologia, adaptada aos limites da bacia hidrográfica, mapearam-se, em escala 1:10.000, os declives dos terrenos, as características pedológicas, as formas erosivas, os limites das propriedades e o uso e cobertura superficial da terra. Para tanto, utilizaram-se de trabalhos de campo, imagens orbitais, fotografias de campo com máquinas manuais e em veículo aéreo não tripulado (VANT) visando o mapeamento de uso da terra, os limites das propriedades e as feições erosivas. Para o levantamento dos solos foram realizados procedimentos técnicos e utilizados equipamentos para coleta de amostras em campo e posterior análise em laboratório. Enquanto que, para a obtenção dos dados de declividade, utilizou-se de técnica automática para mapeamento no software ArcGIS 9.2.

Os mapeamentos de características pedológicas, declividade e formas erosivas foram cruzados no referido software, gerando, ao final, a carta de capacidade de uso das terras. Essa carta foi comparada ao uso da terra de 2016 e às formas erosivas, apontando situações em que se registraram contradições entre a capacidade estabelecida pela referida metodologia e a problemática resultante daquele tipo de uso da terra.

Com a adaptação metodológica à escala e aos procedimentos adotados neste trabalho, foram avaliadas as possibilidades e limitações apresentadas pela metodologia como proposta de zoneamento para o uso adequado a conservação das terras em uma área rural degradada. $O$ resultado do mapeamento produzido a partir da metodologia de Lepsch et al. (1983) foi avaliado comparativamente a outros estudos

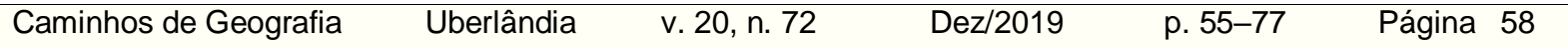


que utilizaram do sistema de capacidade de uso (MENDONÇA et al., 2005; GIBOSHI et al., 2005; CUNHA; PINTON, 2012).

\section{MÉTODO, MATERIAIS E TÉCNICAS CARTOGRÁFICAS}

Para classificação dos terrenos da área estudada no sistema de capacidade de uso das terras foram realizados três distintos mapeamentos: declividade, características pedológicas e formas erosivas. A partir da sobreposição dessas variáveis, os terrenos foram classificados em três grupos de capacidade $(A, B$ e C), que compreendem os tipos de intensidade de uso da terra. Esses três grupos abrangem oito classes (I a VIII), que indicam o grau de limitação de uso, nos quais ainda se adiciona a informação da natureza da limitação, se relativa às características pedológicas (s), à erosão (e) ou ao excesso de água (a).

Apresentam-se a seguir os procedimentos adotados para o mapeamento da declividade, características pedológicas (textura, permeabilidade e profundidade), formas erosivas (sulco, ravina e voçoroca), do uso e cobertura superficial da terra (2016) e as técnicas utilizadas no ArcGIS 9.2 para combinação das variáveis físicas e elaboração da carta de capacidade de uso das terras de acordo com Lepsch et al. (1983).

\section{Declividade}

A base para o mapeamento da declividade constituiu-se da digitalização das informações referentes à topografia, curvas de nível com equidistância de cinco metros e os pontos cotados, das cartas topográficas $057 / 019,057 / 20,058 / 19$ e $058 / 20$, em escala 1: 10.000 , elaboradas pelo Instituto Geográfico e Cartográfico do estado de São Paulo (IGC, 2000).

O declive dos terrenos foi levando de forma automática através da ferramenta Create TIN fromfeature do software ArcGis, onde se inserem as curvas de nível com os valores altimétricos, o Modelo Digital de Elevação (MDE) e os pontos cotados.

As classes foram estabelecidas de acordo com a proposta de Lepsch (1983, p.88-89), em:
A. $\quad \leq 2 \%$ : onde há grande possibilidade de alagamento;
B. $\quad 2$ + $5 \%$ : terrenos com tendência ao alagamento;
C. $\quad 5+10 \%$ : de acordo com os autores consistem em uma classe de declividade moderada, com riscos severos à erosão quando de cultivos intensivos;
D. $10+15 \%$ : declives acentuados, sujeitos à formação de enxurradas, e limite máximo, $15 \%$, para utilizar máquinas no preparo do solo ou colheita (DE BIASI, 1992);
E. $\quad 15+47 \%$ : terrenos não aptos ao uso de maquinário agrícola e com severas limitações devido ao declive muito acentuado;
F. $\quad \geq 47 \%$ : de acordo com a Lei $12.651 / 12$, Art.11,

Em áreas de inclinação entre $25^{\circ}$ e $45^{\circ}$ serão permitidos o manejo florestal sustentável e o exercício de atividades agrossilvipastoris, bem como a manutenção da infraestrutura física associada ao desenvolvimento das atividades, observadas boas práticas agronômicas, sendo vedada a conversão de novas áreas, executadas as hipóteses de utilidade pública e interesse social.

Nesse procedimento automático, ao triangular os valores altimétricos das curvas de nível, foram constatados erros, sobretudo nas vertentes côncavas e em alguns setores das convexas, onde a triangulação e as respectivas medidas ocorreram dentro da mesma curva de nível. Nesses setores, foram realizados ajustes manuais, editando os polígonos e refazendo o cálculo do declive, com a fórmula indicada por De Biase $(1970$, p.48), pela distância correta entre as curvas de nível; a declividade obtida em graus foi ajustada para porcentagem, de acordo com a tabela presente em Lepsch (1983, p.140).

\section{Carta de características pedológicas}

Para o mapeamento das características pedológicas da área estudada, considerou-se a metodologia proposta por Lepsch et al. (1983), em que se caracteriza os solos por sua profundidade, textura e permeabilidade. Tais dados, segundo a proposta adotada, devem ser obtidos para as camadas

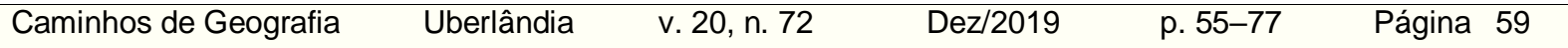


superficial e subsuperficial. O termo camada, utilizado pelos autores, foi mantido visto que não se trata de análise pedológica típica, em que os dados são obtidos por horizontes dos solos, mas de dados obtidos em profundidades que foram estabelecidas pela metodologia, assim como por variações identificadas em campo.

Em um primeiro momento foram selecionados quarenta e quatro pontos de coleta, totalizando oitenta amostras coletadas. Ressalta-se que, em alguns pontos, foram coletadas apenas a amostra de superfície, devido à baixa profundidade do solo. A escolha desses pontos teve como fundamento as observações em campo e da topografia da área estudada, obedecendo aos princípios da topossequência.

Em campo, com uso de um trado foram coletadas duas amostras deformadas por ponto: a primeira foi retirada de cinco a vinte centímetros de profundidade, compreendendo a camada superficial; na segunda amostra, da camada subsuperficial, fez-se análises em campo com as amostras removidas a partir de $20 \mathrm{~cm}$ de profundidade. Nessas análises, avaliaram-se, de acordo com orientações de Santos et. al (2015), a pegajosidade, plasticidade, textura e a cor. A partir do momento em que se identificava uma diferença em relação à amostra da camada superficial, coletava-se a amostra como da camada subsuperficial, anotando a profundidade que a mesma foi encontrada.

Todas as amostras foram embaladas em sacos plásticos, rotuladas com número da amostra, coordenadas do Global Position System (GPS), profundidade do perfil e profundidade das camadas, e encaminhadas para o Laboratório de Solos da Escola Superior de Agricultura Luís de Queiroz (ESALQ), Universidade de São Paulo (USP), campus de Piracicaba, para quantificação das frações granulométricas e avaliação da textura. Posteriormente definiu-se a textura das camadas de acordo com a proposta da National Agriculture Statistics Service (USDA, 1956), indicada pela EMBRAPA (1979) e utilizada por Lepsch et al. (1993).

Ainda, em cada um dos pontos de coleta, perfurou-se o solo até uma profundidade máxima de três metros, sendo menor a profundidade perfurada quando de contato lítico ou pedregosidade.

Em seguida, na seleção dos pontos amostrais para levantar a condutividade hidráulica (permeabilidade) das camadas, as informações de textura, composição granulométrica e profundidade de cada amostra coletada e analisada, foram avaliadas conjuntamente, de maneira a formar grupos em que tais informações apresentaram semelhanças, resultando na seleção de 16 pontos amostrais representativos desses grupos.

Para coleta do material em campo, quando da camada superficial do solo, limpou-se o terreno em superfície, assim como removeu-se entre cinco a dez centímetros de profundidade, para posterior inserção do cilindro com o martelo de Ulhand. Já para aquelas da camada subsuperficial, abriu-se uma trincheira com $70 \mathrm{~cm}$ de largura e $20 \mathrm{~cm}$ de espessura, com profundidade de acordo com a camada subsuperficial. As amostras coletadas nos cilindros foram embaladas com papel alumínio e embrulhadas com plástico bolha, etiquetadas e registradas com as coordenadas geodésicas do GPS.

Posteriormente, encaminharam-se as amostras para o Laboratório de Engenharia de Biossistemas (LEB), da USP - ESALQ, campus de Piracicaba (SP), no qual foram realizadas as análises de condutividade hidráulica (permeabilidade). Nessa análise, o laboratório utilizou da metodologia descrita por Klute (1965), com permeâmetro de carga constante (bureta de Mariotte, cilindro adicional, cilindro de ulhand, tela para suportar o solo e proveta com percola). No cálculo do valor da condutividade foi utilizada a Lei de Darcy. Os resultados foram classificados de acordo com Lepsch et al. (1983), sendo: moderada para valores de $5+150 \mathrm{~mm}$ de água percolada por hora; e lenta quando de $<5 \mathrm{~mm}$ de água percolada por hora.

A partir dos resultados tabelados, seguindo as orientações presentes em Lepsch (1983, p.64-73), os solos foram classificados em três conjuntos de números. O primeiro indicativo da profundidade total do solo, sendo: (1) muito profundos (mais de dois metros); (2) profundos (um a dois metros); e (3) moderadamente profundos ( 0,5 a um metro). Os dois números que seguem se referem a textura da camada superficial e subsuperficial, respectivamente, sendo: (2) textura argilosa (com teor de argila 
entre 35 e 50\%); (3) textura média (com teor de argila menor que 35\%, teor de areia maior que 15\% e de silte menor que 50\%); e (5) textura arenosa (com teor de argila inferior a $15 \%$ e de areia superior a $70 \%$ ). Os últimos dois números correspondem à permeabilidade da camada superficial e subsuperficial, respectivamente, sendo: (2) moderada (níveis de 5 a $150 \mathrm{~mm}$ de água percolada por hora); e (3) lenta (inferior a $5 \mathrm{~mm}$ de água percolada por hora).

Para o mapeamento das classes temáticas, no software ArcGis foram adicionados os pontos de coleta de solo; a estes, na tabela de atributos, foram acrescentadas colunas, inserindo todas as informações levantadas em campo (profundidade, se subordinado ao hidromorfismo, cor, pedregosidade) e laboratório (textura e permeabilidade da camada superficial e subsuperficial). Espacializadas essas informações, avaliou-se o relevo de entorno do ponto, considerando sua posição na topossequência e traçando os possíveis limites de cada conjunto de características pedológicas levantadas. Para o caso dos solos subordinados ao hidromorfismo, nas imagens orbitais do satélite Quickbird de 2013, com resolução de 0,6m, constatou-se a presença de água pela tonalidade mais escura e desenvolvimento de vegetação características de áreas úmidas, como graminosas e herbáceas; os limites dessa classe de solo foram reambulados em campo.

\section{Feições erosivas}

Para a identificação das feições erosivas foram utilizadas imagens orbitais do satélite Quickbird de 2013, com reambulação dos dados em campo no ano de 2016.Para diferenciar as feições erosivas lineares, seguindo a revisão apresentada por Zanatta, Lupinacci e Boin (2017), consideraram-se sulco como pequenas incisões verticais passíveis de correção por procedimentos simples de preparo do solo (LAL, 1990; SALOMÃO, 2012); ravinas como incisões mais profundas, com formação de fundo com talude (FOOKES, 2007; KARMAN, 2008); e voçorocas quando a erosão linear atinge e expõe o lençol freático (DEPARTAMENTO DE ÁGUA E ENERGIA ELÉTRICA (DAEE); IPT, 1989; FOOKES, 2007; SALOMÃO, 2012).Através das definições mencionadas, em campo e nas imagens orbitais, distinguiram-se as formas erosivas pela profundidade, dimensão e presença de água no fundo da forma erosiva(Figura 2).

Figura 2 - Identificação das feições erosivas em sulco, ravina e voçoroca em campo e imagens orbitais.

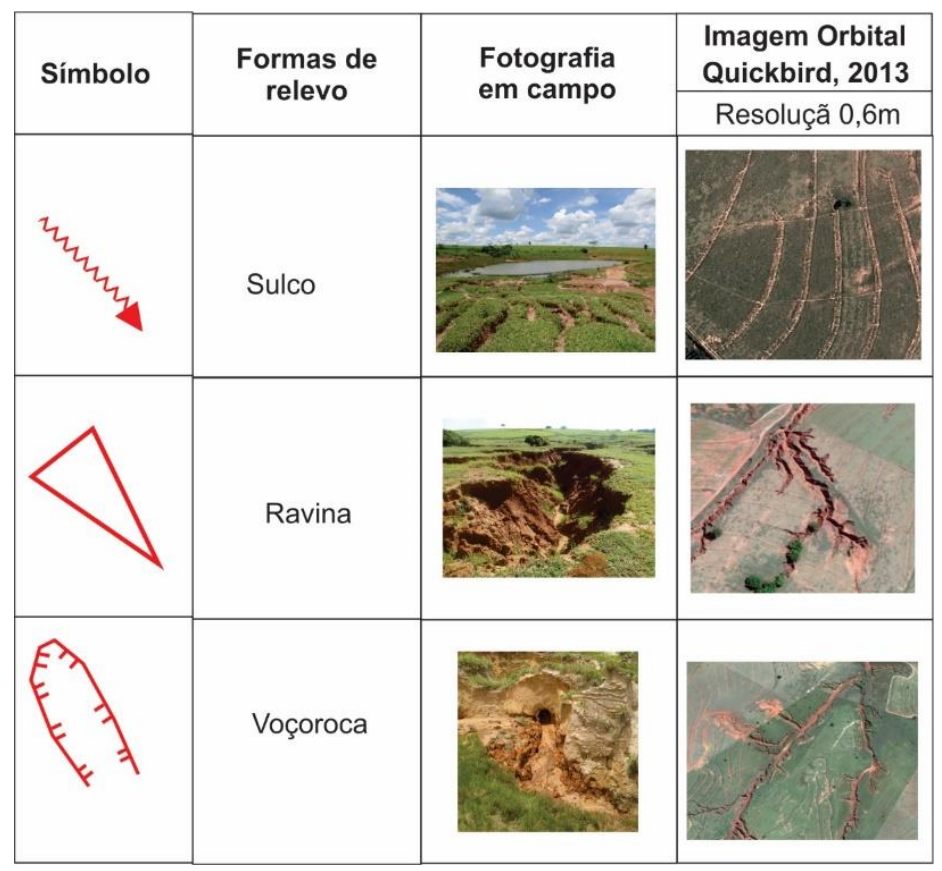




\section{Sistema de Capacidade de Uso}

Para a elaboração da capacidade de uso dos terrenos de acordo com a proposta de Lepsch et al. (1983), foram necessários os dados de limite das propriedades, características pedológicas, declividade e formas erosivas; os limites das propriedades rurais foram levantados em campo.

Com os mapeamentos de características pedológicas e declividade, no Programa ArcGis utilizou-se a ferramenta Intersectpara cruzar as referidas feature class. Ao resultado foram sobrepostas as featureclass das feições erosivas.

Para definir as subclasses, foram realizadas algumas adaptações quanto as características do solo e interpretações da geomorfologia, objetivando adequar à pesquisa e à área estudada (Tabela 8).

Tabela 1 - Características identificadas na área estudada e adaptações para definição das subclasses.

\begin{tabular}{|l|l|l|l|}
\hline \multicolumn{2}{|l|}{ Limitação pela erosão presente ou risco de erosão (e) } & \multicolumn{2}{l|}{ Limitação por excesso de água (a) } \\
\hline Lepsch et al. (1983) & Adaptação & $\begin{array}{l}\text { Lepsch et } \\
\text { al. (1983) }\end{array}$ & Adaptação \\
\hline $\begin{array}{l}\text { Mudança textural } \\
\text { abrupta }\end{array}$ & $\begin{array}{l}\text { Mudança de permeabilidadede } \\
\text { moderada (2) na camada } \\
\text { superficialpara lenta (3) em } \\
\text { subsuperfície }\end{array}$ & $\begin{array}{l}\text { Lençol } \\
\text { freático } \\
\text { elevado }\end{array}$ & Afloramento de água \\
\hline $\begin{array}{l}\text { Erosão em sulco raso } \\
\text { e profundo }\end{array}$ & $\begin{array}{l}\text { Considerou-se "erosão em sulco } \\
\text { raso" como sulco e "erosão em sulco } \\
\text { profundo" como ravina }\end{array}$ & $\begin{array}{l}\text { Risco de } \\
\text { inundação }\end{array}$ & $\begin{array}{l}\text { Área de terraço e planície } \\
\text { fluvial e talvegue da voçoroca }\end{array}$ \\
\hline
\end{tabular}

Em seguida, determinou-se, através da presença ou não de subclasse e da natureza da limitação, as classes:

I.Declives $A$ ou $B$ que não apresentaram qualquer restrição ao uso do solo por risco ou presença de erosão, limitação do solo ou por excesso de água;

II.Declive A e B quando da presença de qualquer subclasse;

III.Declive C; sulcos frequentes; ou declives B com solos de permeabilidade lenta na camada de subsuperfície;

IV.Declive D; sulcos muito frequentes; ou ravinas ocasionais;

VI.Declive $C$ ou $D$ em solos com permeabilidade lenta na camada de subsuperfície; sulcos muito frequentes; ou ravinas frequentes;

VII.Declive E; ravinas muito frequentes; ou solos moderadamente profundos com perfil de textura arenosa;

VIII.Declive F; solos muito rasos; solos subordinados ao hidromorfismo; ou voçoroca.

Seguindo a metodologia, para os dados de sulcos e ravinas aferiu-se a frequência desses, sendo: ocasionais, quando distanciados mais de 30 metros; frequentes, quando distanciados menos de 30 metros e ocupando área inferior a 75\%; e muito frequentes quando a distância entre as formas erosivas for inferior a 30 metros, mas ocupando área superior a $75 \%$. A área considerada para o cálculo foi a do polígono resultante do cruzamento entre as características pedológicas e declividade, apresentados no tópico que segue.

As características necessárias para a classe $V$, que classifica as terras planas, não sujeitas à erosão e impróprias para culturas anuais, não foram encontradas na área estudada.

As classes I, II, III e IV compreendem o Grupo A, em que as terras são passíveis de utilização para culturas anuais, perenes, pastagens e/ou reflorestamento e vida silvestre. As classes V, VI e VII inserem-se no Grupo B, diferenciando-se do primeiro grupo por serem impróprias as culturas anuais e perenes. No Grupo C, apropriadas apenas para proteção da flora e fauna silvestre, recreação ou 
armazenamento de água, encontra-se a classe VIII. O aumento do algarismo indica a redução da capacidade de uso, enquanto nos grupos esse aumento indica maiores problemas de conservação dentro da adaptabilidade do uso que o grupo designa (Figura 3 ).

Figura 3 - Resumo da variação do tipo e da intensidade máxima de utilização da terra sem risco de erosão acelerada em função das classes de capacidade de uso.

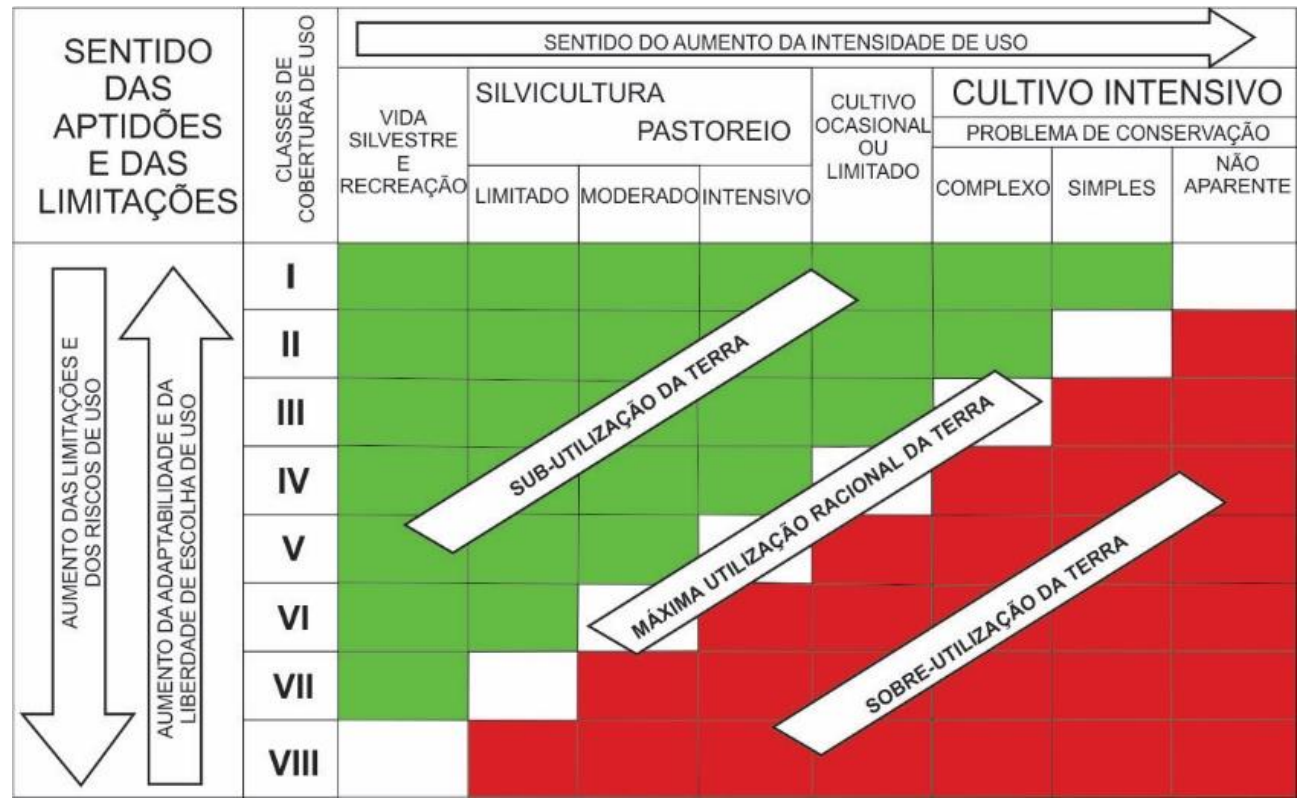

Fonte - LEPSCH et al. (1983. p.21). Adaptado por ZANATTA, F.A.S.

Com o resultado, no featureclass gerado foi criada uma coluna, em que, de acordo com a combinação das classes temáticas, os terrenos foram classificados na classe e subclasse em que se enquadravam. Para confecção da carta, na tabela de atributos criaram-se duas colunas denominadas "Classe" e "Subclasse". Com o uso da ferramenta dissolve foram gerados dois featureclass, um composto da classe e outro apenas da subclasse. No primeiro, foram mapeadas as classes com as cores indicadas por Lepsch et al. (1983, p. 21-22). No segundo, os limites das subclasses foram cartografas como linhas pontilhadas, adicionando o tipo de limitação ("a" e/ou "e" e/ou "s") sobre cada polígono. As informações da área ocupada por cada classe e subclasse foram levantadas de forma quantitativa, em porcentagem.

\section{Uso e cobertura superficial da terra}

Para o mapeamento do uso e cobertura superficial da terra foi utilizada a imagem orbital do satélite Quickbird 2013, assim como reambulação das classes identificadas em trabalhos de campo no ano de 2016.

As chaves de interpretação da imagem orbital seguiram as indicações de Florenzano (2007), considerando: cor; textura; tamanho; formas regulares e irregulares; padrão; e localização geográfica dos objetos detectados pelos sensores remotos.

O mapeamento foi realizado de modo manual, identificando as classes de cobertura superficial: floresta estacional semidecidual; vegetação de área úmida; reflorestamento; silvicultura; cana-deaçúcar; pasto; pasto sujo. Na interpretação das classes, à exemplo, diferenciou-se silvicultura de reflorestamento pelo padrão homogêneo observado na primeira e uma textura rugosa, representativas do reflorestamento, com maior diversidade e porte de espécie que refletem em uma cobertura de padrão heterogêneo; a cana-de-açúcar, de textura homogênea, foi diferenciada da silvicultura pela cor, sendo a cana-de-açúcar de tonalidade mais clara. 
Para análise, quantificaram-se as classes em área em porcentagem, constatando quais os usos predominantes da área, comparando posteriormente com as formas erosivas e as classes de capacidade de uso da terra.

\section{RESULTADOS E DSICUSSÃO}

Os dados obtidos na área estudada foram comparados a outros estudos que utilizaram da metodologia de Lepsch et al. (1983). Giboshi et al. (2005) levantaram as classes de capacidade a partir da declividade dos terrenos e das características físicas, químicas e de drenagem dos solos, na micro bacia do rio Sapé (PB); Mendonça et al. (2005) estabeleceram a capacidade a partir da declividade e das características físicas e químicas dos solos no município de Santo Antônio do Jardim (SP); e Cunha e Pinton (2012), que fizeram uso da declividade, das características físicas dos solos e da presença de erosão, identificaram a capacidade de uso das terras na bacia hidrográfica do Córrego do Cavalheiro, em Analândia, setor centroleste do estado de São Paulo.

$\mathrm{Na}$ área estudada, as subbacias do ribeirão Areia Dourada, de acordo com a metodologia do Sistema de Capacidade de Uso, levantaram-se que $96,76 \%$ da área apresenta risco de erosão ou erosão presente; ainda, em 2,81\% tem-se terrenos com excesso de água e em $21,27 \%$ com limitações relativas ao solo (Quadro 1).

Quadro 1 - Área em porcentagem da natureza das limitações da capacidade de uso das terras.

\begin{tabular}{lr}
\hline Natureza das limitações & Área (\%) \\
\hline & 1,76 \\
Excesso de água (a) & 1,20 \\
Erosão presente e/ou risco de erosão (e) & 73,88 \\
Relativas ao solo (s) & 0,27 \\
Erosão presente e/ou risco de erosão (e) e excesso de água (a) & 1,61 \\
Erosão presente e/ou risco de erosão (e) e relativas ao solo (s) & 21,27 \\
\hline
\end{tabular}

Os poucos terrenos do Grupo A, com capacidade de uso I, somente 0,83\% (Figura 4) da superfícienão apresentaram qualquer tipo de restrição e, portanto, são adaptados, de acordo com a metodologia, ao cultivo intensivo, com problemas simples de conservação.

Figura 4 - Área em porcentagem das classes de capacidade de uso da terra nas subbacias do ribeirão Areia Dourada, Marabá Paulista (SP).

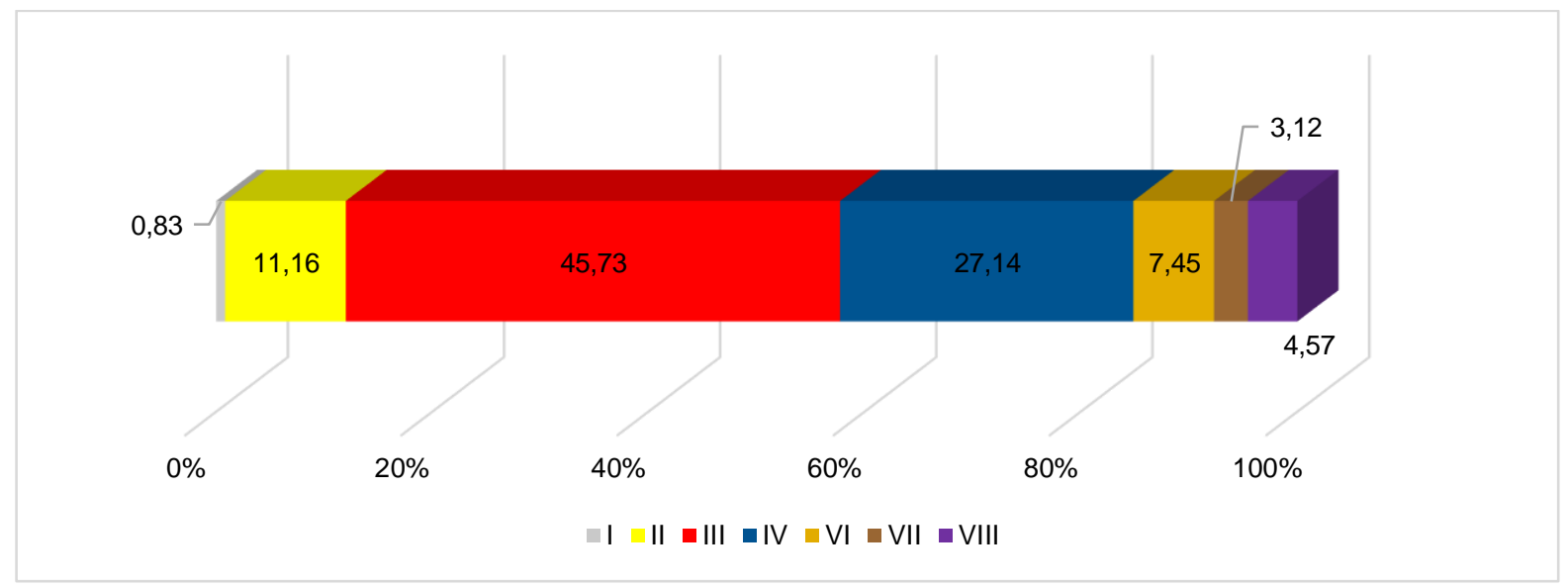


A classe I localiza-se em alguns setores dos topos nas subbacias W e S (Figura 5), em que não há qualquer fator limitante identificado pelas variáveis analisadas (características pedológicas, declividade e feições erosivas), com declives $\mathrm{A}(\leq 2 \%)$.

Figura 5 - Carta de capacidade de uso das terras nas propriedades rurais localizadas nas subbacias do ribeirão Areia Dourada, Marabá Paulista (SP).

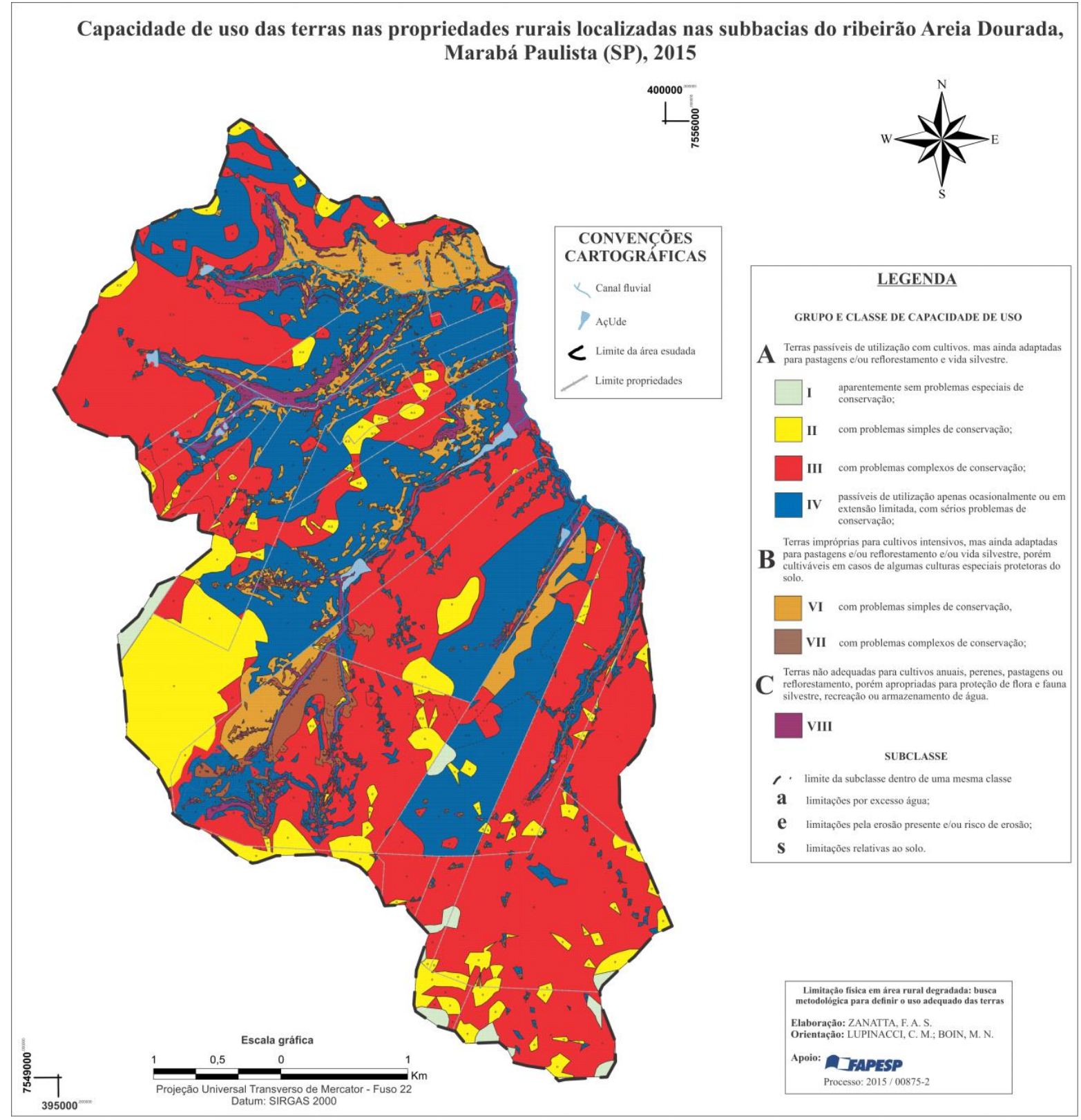

Essa classe de capacidade também ficou restrita aos topos no trabalho de Cunha e Pinton (2012), sendo caracterizada como uma pequena parcela da área onde o declive é $\leq 2 \%$ combinado ao Latossolo Vermelho Amarelo - os autores não realizaram o levantamento quantitativo da área ocupada por essa classe; Mendonça et al. (2005) e Giboshi et al. (2005) não identificaram combinações da classe I. Assim, como neste trabalho, a classe I, por seus atributos específicos de declividade plana, ausência de processos erosivos e determinadas características pedológicas, apresentam baixa representatividade espacial. Deste modo, de maneira geral, as parcelas de terras que apresentam características físicas que suportam o uso intensivo são bem reduzidas.

\begin{tabular}{llllll}
\hline Caminhos de Geografia & Uberlândia & v. 20, n. 72 & Dez/2019 & p. 55-77 & Página 65
\end{tabular}


Ao todo, o grupo A, de terras passíveis para utilização com cultivos, compreendeu $84,46 \%$ das subbacias do ribeirão Areia Dourada, abrangendo, além da classe I, as classes II, III e IV. Dessa hierarquia, os terrenos designados por algarismos maiores apresentam menor capacidade de uso. No estudo de Mendonça et. al (2005), esta classe compreendeu 57,7\% da área mapeada pelos autores, enquanto para Giboshi et al. (2005), ocorreu em aproximadamente $40 \%$.

A classe II, presente em $11,16 \%$ das subbacias, localiza-se nas áreas de topo e em alguns setores das vertentes convexas, quando em declive B (2+5\%); este declive, segundo Lepsch et al. (1983), pode proporcionar a formação de enxurradas e erosão, o que estabelece essa classe com risco moderado à erosão. Em alguns setores, como nas subbacias $\mathrm{W}$ e $\mathrm{S}$, desenvolveram-se sulcos ocasionais (distanciados em mais de $30 \mathrm{~m}$ entre si).

Cunha e Pinton (2012) encontraram a classe II apenas em situações de declives $<2 \%$ e de 2 a $5 \%$, em que os solos apresentavam alguma propriedade que determinou restrições, localizados em pequenas áreas no reverso da cuesta. Giboshi (et. al, 2005) constataram essa classe em $12,8 \%$ da área estudada, apenas em situações de declive de 0 a 3\%, com Latossolo, Argissolos ou Cambissolo, localizados principalmente nas áreas de topo. Mendonça et al. (2005) também restringiram esta classe a apenas um intervalo de declividade, de 0 a $2 \%$, combinado com Argissolo Vermelho Amarelo.

A classe III compreendeu a maior área nas subbacias estudadas, abrangendo $45,73 \%$ do total, com maior representatividade espacial de todas as classes de capacidade. Foram definidas em função de declive $\mathrm{C}(5 \vdash 12 \%)$ e/ou com erosão em sulcos frequentes (distanciados em mais de $30 \mathrm{~m}$ entre si, ocupando uma área inferior a $75 \%$ ), ou nos declives B (2r5\%) em solos com permeabilidade lenta na camada de subsuperfície. Para Lepsch et al (1983), essas áreas são próprias para culturas temporárias adaptadas ao clima, mas apresentam risco severo à erosão.

Cunha e Pinton (2012) encontraram essa classe em declives de 5 a 12\% em Argissolo, Nitossolo ou Neossolo, na presença de formas erosivas ou problemas relacionados às propriedades dos solos. $\mathrm{Na}$ área mapeada pelos referidos autores, espacialmente essa classe compreendeu a maior parcela dos terrenos, com resultados similares a este artigo. Já nos estudos realizados por Giboshi et. al (2005) e Mendonça et al. (2005) houve diferença significativa em relação a espacialização da classe III. Ambos os autores a restringiram ao declive, de 3 a $6 \%$ e de 2 a $5 \%$, respectivamente, independente da classe de solo ou características pedológicas. Na área mapeada por Giboshi et al. (2005), esta classe ocorreu em 13\%, enquanto Mendonça et al. (2005) não apresentaram os dados quantitativos da área ocupada por classe.

A classe IV caracteriza-se pelo risco severo à erosão quando o uso se faz por culturas anuais. Os terrenos foram classificados pelo declive $D(10+15 \%)$ com sulcos muito frequentes (menos de $30 \mathrm{~m}$ entre si, ocupando mais de $75 \%$ da área), ravinas ocasionais (mais de $30 \mathrm{~m}$ de distância entre si), como também quando da permeabilidade lenta na camada de subsuperfície em declives C (5+10\%). Essa classe ocorreu sobre $27,14 \%$ da área, localizando-se nas baixas vertentes e concavidades da subbacia $S$ e nas vertentes com solos com permeabilidade lenta na camada de subsuperfície nas subbacias SW, W e N.

Giboshi et al. (2005) mapearam essa classe apenas quando da combinação de qualquer classe de solo com declives de 6 a 9\%, compreendendo 14\% das terras. Mendonça et. al. (2005) constataram essa classe em declives de 2 a $5 \%$ ou de 5 a 10\%, quando associados às características químicas do solo, como limitações na fixação de fósforo, em Argissolo Vermelho Amarelo Distrófico Abruptico ou Plíntico, ou Neossolo Quarzarênico, enquanto os declives de 5 a $10 \%$ quando combinado a Luvissolos ou Neossolos Litóticos. Pinton e Cunha (2012) identificaram a classe IV em declives de 12 a $20 \%$ em Argissolo ou Nitossolo ou Latossolo.

As diferenças quantitativas da área da classe que compõe o Grupo A, em comparativo aos trabalhos de Giboshi et. al (2005) e Mendonça et. al (2005) ocorrem pela ausência da classe I nesses trabalhos, bem como a limitação das classes II, III e IV a uma classe específica de declividade, reduzindo significativamente a área deste Grupo. Já nesta pesquisa e na de Cunha e Pinton (2012) 
foram utilizados intervalos maiores de declividade, resultando em maior representação espacial deste Grupo.

O grupo $\mathrm{B}$, de terras impróprias para cultivo, adaptadas à pastagem ou reflorestamento, compreendeu $10,57 \%$ da área estudada entre as classes $\mathrm{VI}$, com problemas simples de conservação, e VII, com problemas complexos de conservação. Em Giboshi et al. (2005), esta classe ocorreu em $45 \%$ da área mapeada, enquanto para Mendonça et. al (2005) em 37,6\%. Este grupo também teve maior abrangência dos terrenos no trabalho de Cunha e Pinton (2012). Tais diferenças ocorrem pelos critérios adotados pelos autores, principalmente no caso de Giboshi et al. (2005), bem como em função das características específicas dos terrenos mapeados nos três trabalhos, com maior ocorrência de declives mais acentuados, que distingue do universo estudado neste artigo.

A classe $\mathrm{VI}$ incidiu em $7,45 \%$ de toda área, na qual admite-se a presença de ravinas frequentes (mais de 30m de distância entre si) (LEPSCH et al., 1983), situações que ocorreram nas vertentes a W da alta subbacia W, e na subbacia SW, na baixa vertente a $\mathrm{E}$. A classe VI também caracterizou terrenos cuja restrição deriva das características pedológicas e/ou do declive, como as vertentes ao $\mathrm{N}$ da subbacia $\mathrm{N}$, em solos moderadamente profundos $(0,50$ a $1,00 \mathrm{~m})$ e de permeabilidade lenta na camada de subsuperfície em declive D (10r15\%).

Giboshi et. al (2005) identificaram esta classe em 13\% da área, a qual ocorre de maneira determinante sobre todas as classes de solo encontradas em declives de 9 a $12 \%$. Mendonça (et al, 2005) constataram esta classe também associada ao declive, entre 10 e $20 \%$, sendo de 5 a $10 \%$ quando de Argissolo Vermelho Amarelo Abruptico com fase pedregosa ou rochosa. Cunha e Pinton (2012), levantaram que esta classe ocorre em Neossolo Quartzarênico com declive C, Neossolo Ltólico, Nitossolo ou Argissolo, quando de declive 12 a 20\%, associados a presença de formas erosivas, e Latossolo Vemerlho-Amarelo quando de declive 20 a 45\%, também associado a presença de formas erosivas; no trabalho de Cunha e Pinton (2012), esta classe apresentou significativa abrangência espacial.

A classe VII abarcou 3,12\% dos terrenos, em situações de ravinas muito frequentes (menos de $30 \mathrm{~m}$ de distância entre si), ocupando $75 \%$ da área. Essa classe incidiu no interflúvio situado na alta subbacia $\mathrm{W}$, em solos pouco profundos $(0,5$ a $1,00 \mathrm{~m})$ e de maneira bem fragmentada e dispersa em alguns setores de concavidades em vertentes, com declive $E(15 \vdash 47 \%)$.

Cunha e Pinton (2012) constataram esta classe quando ocorrem declives $\geq 45 \%$ e Nitossolo ou Latossolo, quando Neossolos Litólicos ou Argissolos estão combinados a declives de 30 a $45 \%$, e na presença de Neossolo Quartzarênico quando se registram declives de 12 a 20\%. Giboshi et al. (2005) estabeleceram novamente uma relação direta com a inclinação dos terrenos, sendo aqueles de 12 a $18 \%$ determinantes para serem inseridos na classe VII, independente da classe de solo ou características pedológicas. Por esta classe de declive compreender extensa parcela da área estudada pelos autores, a classe VII incidiu sobre 32\% dos terrenos, sendo a maior em abrangência. Já Mendonça et al. (2005), identificaram essa classe em situações onde o declive de 10 a $20 \%$ estava associado à Argissolo Vermelho Amarelo Abruptico, com fases pedregosas e rochosas; assim como declives de 20 a 40\%, associados a Argissolo Vermelho Amarelo Abruptico ou Neossolo Litólico Eutrófico.

Nas subbacias do ribeirão Areia Dourada, 4,57\% das terras encontraram-se no grupo C, compondo a classe VIII, com capacidade para proteção da fauna e flora silvestre, recreação ou armazenamento de água. Essa classe ocorreu com maior intensidade nas subbacias $\mathrm{N}$ e $\mathrm{W}$, de relevo mais movimentado pelas rupturas topográficas e/ou com afloramentos de água e pela presença de voçorocas. Nas outras bacias, $\mathrm{S}$ e SW, de relevo menos movimentado, encontram-se restritas a alguns setores das concavidades e nos fundos de vale, quando de área de planície e terraço fluvial ou, no caso da subbacia SW, no talude erosivo e na base da voçoroca.

Mendonça et al. (2005) identificaram uma porcentagem ainda menor de áreas a serem preservadas, abrangendo apenas 1,7\% das terras, em situações em que o declive dos terrenos de 20 a $40 \%$ localizam-se em Argissolo Vermelho Amarelo Distrófico Abruptico Plíntico ou Neossolos 
Quartzarêncios Òrticos típicos. Giboshi et. al, (2005) mapearam a classe VIII em 19,5\% das terras. No entanto, neste montante os autores consideraram áreas de preservação ambiental protegidas por Lei, de modo que, quando avaliadas apenas das características físicas, como declives $>25 \%$ combinados com Argissolo Vermelho-Amarelo, o terreno classificado como classe VIII atingiu somente $0.6 \%$. Cunha e Pinton (2012) identificaram esta classe em situações de declives $\geq 45 \%$, nas regiões escarpadas, e na presença de voçoroca; embora os autores não tenham realizado o levantamento quantitativo, na espacialização das classes sobre a área estudada, verificou-se também que esta classe é significativamente mais reduzida espacialmente que as demais.

A comparação entre os dados dos estudos analisados e da área pesquisada neste artigo, permitiu constatar que a metodologia adotada aponta reduzida área a ser preservada quando se consideram apenas os critérios estabelecidos por Lepsch et al. (1983). Esse fato realmente ocorre na bacia estudada. Assim, o uso e cobertura superficial da terra na área estudada, no ano de 2016, encontrava-se dominado pelo pasto com razoável manejo (podas e terraços agrícolas, em 74,43\%) e sem qualquer manejo, em 4,54\% dos terrenos (Figura 6). Destacou-se a baixa presença de vegetação nativa do tipo floresta estacional semidecidual, que, de todos os usos levantados, apresentou menor área como cobertura, compreendendo apenas 0,70\% de toda área estudada (Figura 6).

Figura 6 - uso e cobertura superficial da terra nas subbacias do ribeirão Areia Dourada, Marabá Paulista (SP). Área em porcentagem, em 2016.

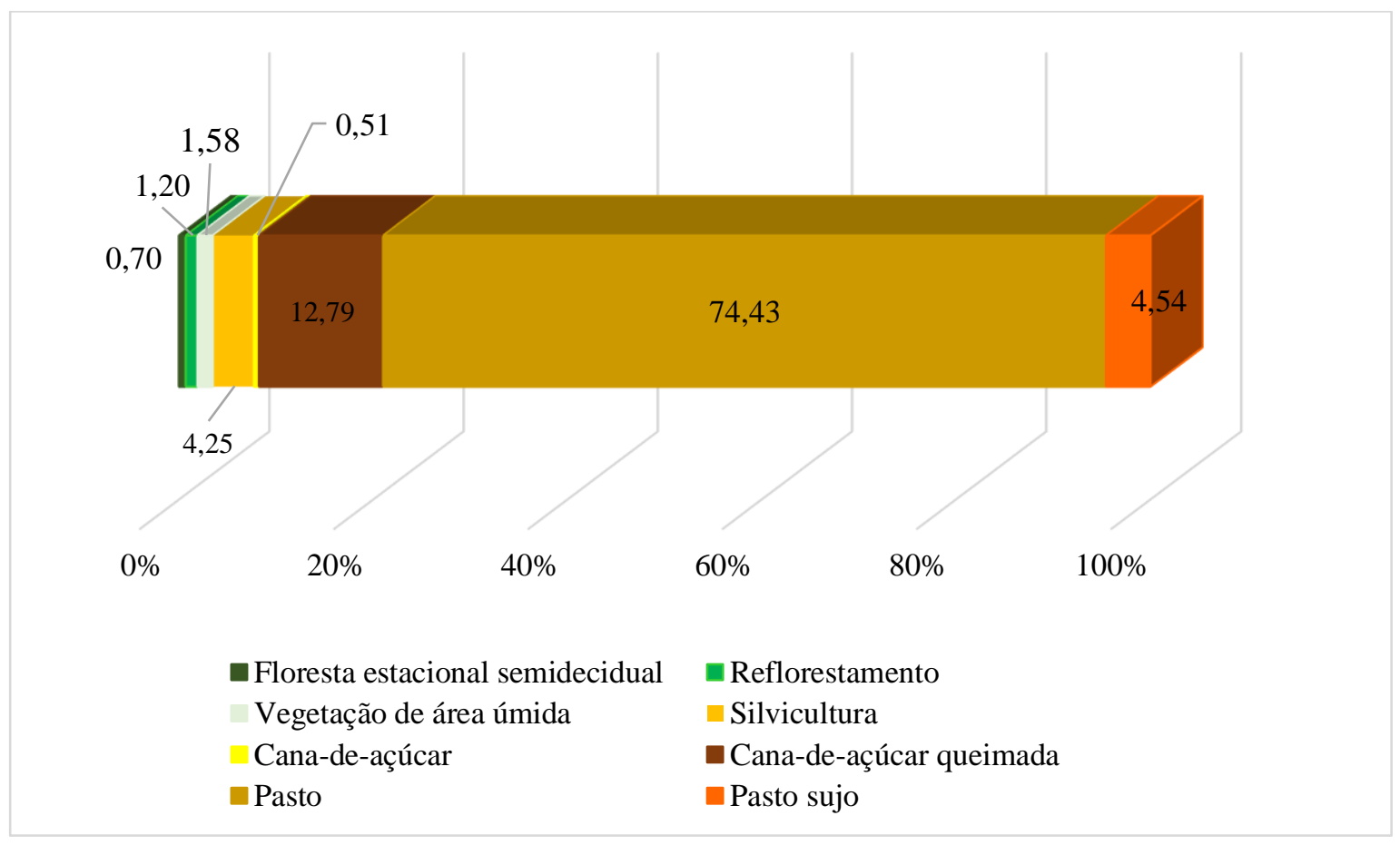

Nos terrenos cultivados com cana-de-açúcar, durante os trabalhos de campo verificou-se $12,79 \%$ se encontravam queimados e utilizados como pasto. De acordo com relatos de trabalhadores, essa situação ocorreu devido à redução das atividades das empresas sucroalcooleiras na região, que encerraram os contratos de arrendamento antes do período de safra, e os proprietários optaram pela queima e expansão da atividade pecuária. Convém destacar ainda que, em todas áreas de pasto, eucalipto e cana-de-açúcar, encontraram-se terraços agrícolas.

De acordo com a metodologia proposta, embora desconsidere aqui as medidas conservacionistas e técnicas necessárias para cada tipo de uso da terra em cada classe, apenas 17,81\% da área estudada apresentaram coberturas que indicam a sobre utilização dos terrenos, de modo que $82,19 \%$ com coberturas que representaram subutilização (Figura 7).

\begin{tabular}{|c|}
\hline Caminhos de Geografia \\
\hline
\end{tabular}


Figura 7 - Classes de capacidade de uso da terra e uso e cobertura superficial da terra. Em verde as situações de subutilização e em vermelho de sobre utilização. Área em \%.

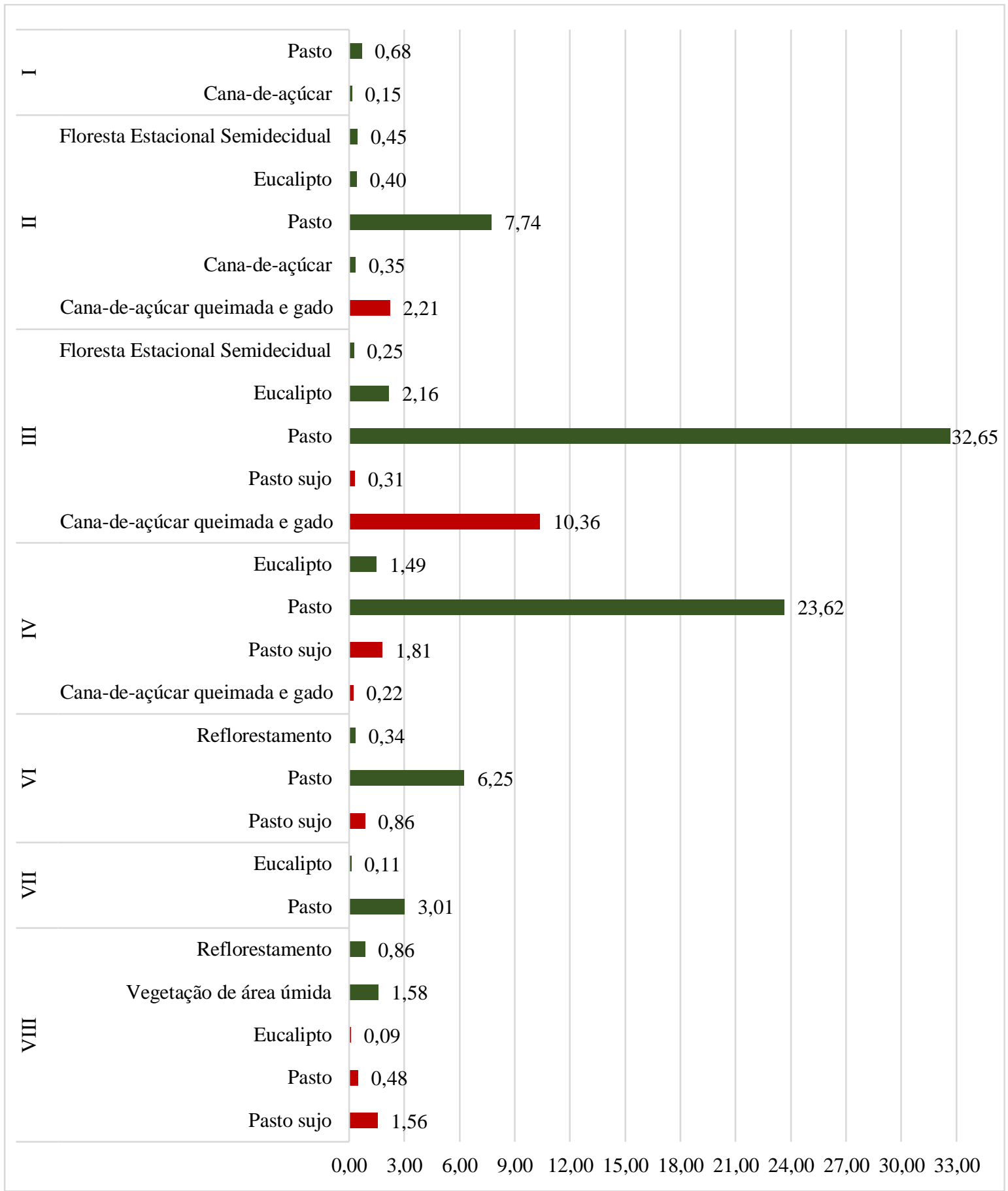

O pasto sujo e a cana-de-açúcar queimada e com gado foram consideradas, de acordo com a metodologia, coberturas com sobre utilização da capacidade em todas as classes que se fazem presentes.

Em relação à ausência de manejo adequado nas áreas de pastagem, Ferreira et al. (2011) em estudo sobre os impactos desta prática, identificaram que o pisoteio animal reduz a densidade e a macro porosidade do solo, o que limita o desenvolvimento do sistema radicular das pastagens em condições de baixa umidade, ou da oxigenação, em condições de excesso de umidade. Para os autores, a pecuária extensiva sem manejo adequado, dentre os sistemas possíveis, constitui naquele mais

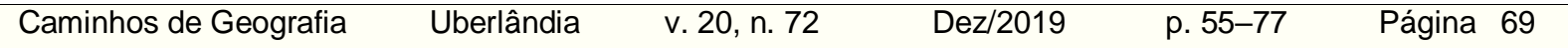


prejudicial ao solo, uma vez que não respeita o ciclo de desenvolvimento das forrageiras, sem a reposição adequada de nutrientes e carbono orgânico. Estas condições favorecem a atuação de pragas, plantas daninhas e, principalmente, a erosão hídrica.

Godoy e Freire (1991) identificaram que a deterioração das pastagens constitui no principal foco de erosão dos solos na bacia do rio Santo Anastácio, em que se encontra a área estudada. Zanatta et al. (2017) registraram que, mais de duas décadas depois dos apontamentos de Godoy e Freire (1991), a deterioração das pastagens ainda constitui no principal catalisador de processos erosivos na alta bacia do ribeirão Areia Dourada.

Sobre o cultivo de cana-de-açúcar em solos arenosos, Corrêa et. al (2016) identificaram modificações nos atributos físicos dos solos. De acordo com os autores, em oito anos de cultivo, as modificações nos solos foram mais intensas que em 40 anos de uso para pastagem, proporcionando aumento da densidade do solo, redução da porosidade total e das taxas de infiltração de água. Tais alterações favoreceram a formação de feições erosivas lineares em toda extensão das vertentes com este cultivo. Ainda, considerando a prática da queimada na área estudada, os solos com cana-de-açúcar, quando submetidos à queima, de acordo Redin et. al (2011), de maneira direta ou indiretamente, sofrem alteração na estrutura física, na composição química e na biologia dos solos, de difícil correção ou reversão dos danos ocasionados, sendo, estes, por vezes, permanentes.

Nas subbacias do ribeirão Areia Dourada, o pasto representa a cobertura de maior abrangência, compreendendo $74,43 \%$ de toda área. No comparativo com o mapeamento do Sistema de Capacidade de Uso, contatou-se apenas $0,48 \%$ em situações de sobre utilização, em terrenos da classe VIII. No entanto, comparando a carta de capacidade com as características físicas e o uso da terra, os sulcos ocorreram em praticamente toda área com uso para pastagem, mesmo naquelas aonde se tem a presença de terraços agrícolas, assim como nas vertentes convexas em solos profundos, de camada superficial arenosa, seguida de média, em declives de 2 r $5 \%$, ou seja, teoricamente de baixa predisposição à formação e desenvolvimento de processos erosivos lineares (Figura 8).

Figura 8 - Sulcos erosivos no setor S da área estudada, em área com capacidade de uso na classe III.

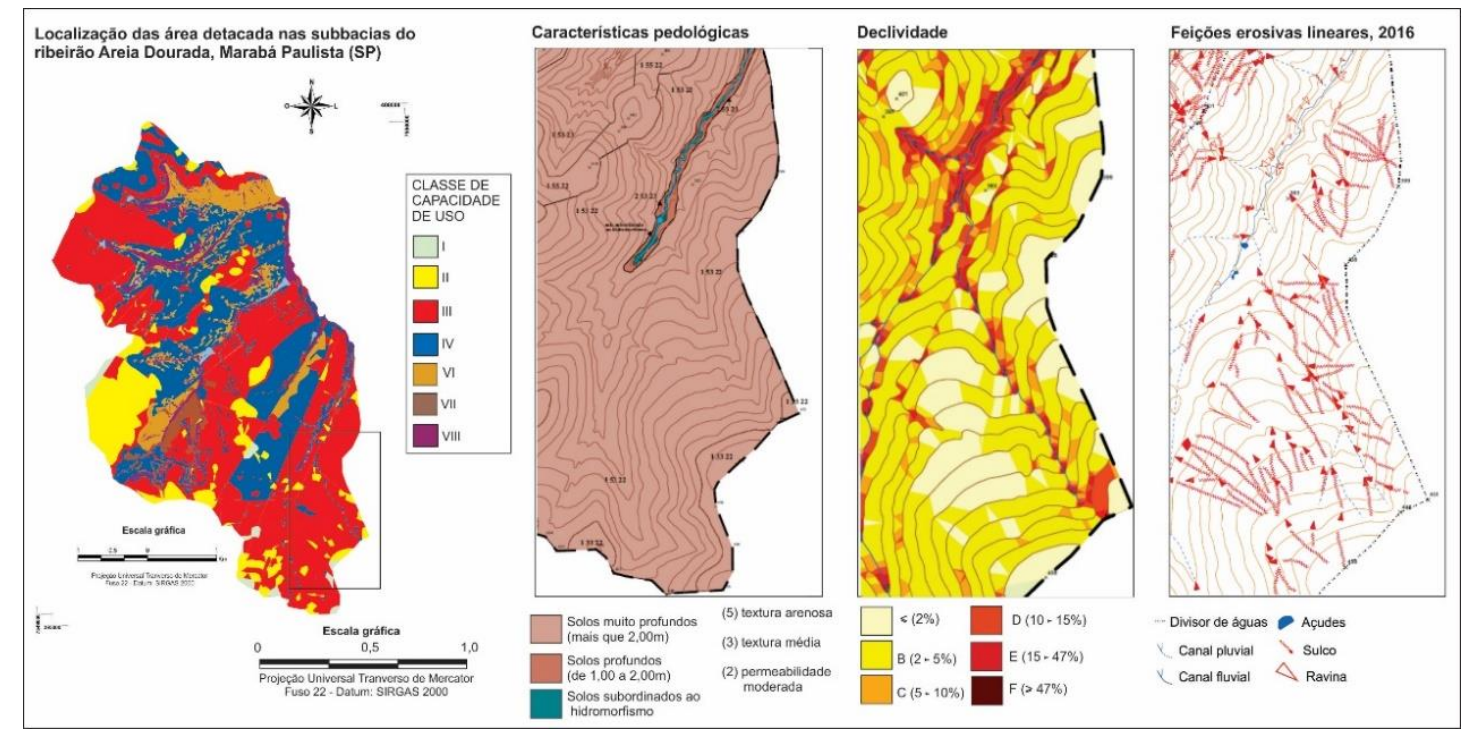

$\mathrm{Na}$ área destacada na Figura 8, as características pedológicas e o declive definem a presença da classe II em alguns setores das vertentes. No entanto, o uso dos terrenos para pastagem promoveu no surgimento de sulcos muito frequentes (menos de $30 \mathrm{~m}$ de distância entre si, ocupando área superior ou igual a $75 \%$ ), reduzindo a capacidade de uso desses terrenos para classe III. Assim, entende-se que essas áreas se encontram em situação de uso inadequado, tendendo a perda progressiva de sua capacidade de uso, enquanto a metodologia indica situação de subutilização. 
Nos terrenos atingidos por ravinas frequentes na classe VI, adaptada às pastagens com uso limitado, identificou-se que tais formas erosivas derivaram do processo de voçorocamento no fundo de vale. Este processo dinamizou a baixa vertente com ravinas através da erosão remontante (Figura 9).

Figura 9 - Desenvolvimento de ravinas em terrenos de classe VI com uso para pastagem, a montante de voçorocamento.

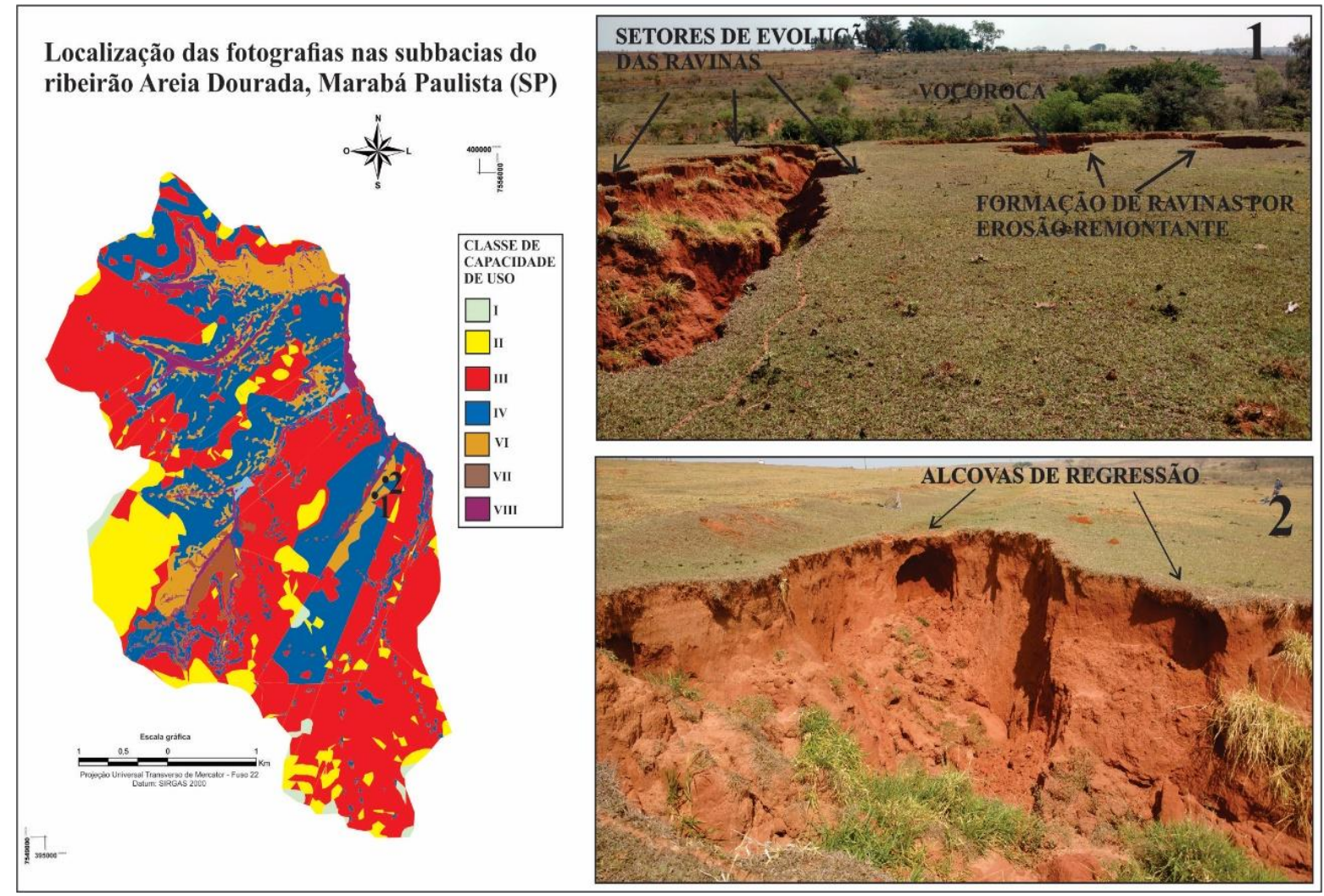

Nessas condições, os terrenos atingidos por ravinas, quando utilizados para pasto, apresentaram maior dinâmica dos processos erosivos, que se desenvolveram com contribuições do pisoteio do gado, que compacta a camada superficial e direciona o fluxo de água de superfície para as ravinas, as quais se desenvolvem para montante. Tal situação erosiva indica que o uso dessas áreas para pasto é inadequado, enquanto a metodologia indica que há capacidade de uso para pastagem.

No comparativo entre a dinâmica erosiva e a cobertura da terra, identificou-se maior desenvolvimento das erosões quando da presença de pasto, que ao dinamizar os terrenos da baixa vertente com ravinas (Figura 9), reduziu a capacidade desses para a classe VI. Ainda, como efeito sistêmico da erosão, as ravinas na baixa vertente proporcionaram em maior dinâmica dos sulcos a montante, sobre a classe IIInas vertentes a E (Figura 10).

Nas vertentes à W, sobre a mesma classe de capacidade de uso, III, com cana-de-açúcar constatouse menor dinâmica dos processos em relação aos terrenos utilizados para pastagem, registrando presença de sulcos e manchas de solo exposto (Figura 10), tais dados indicam que esse uso tende a reduzir a capacidade de uso, sendo inadequado para as classes II e III.

Mesmo com menor quantidade de feições erosivas nas áreas de cana-de-açúcar, em relação à pastagem, destacadas na figura 10, a presença dessas formas indicou que essa cobertura não exerce a proteção adequada aos solos predominantemente arenosos submetidos a erosividade das chuvas, sobretudo na primavera e verão, que variaram de 1500 a $3500 \mathrm{MJ} . \mathrm{mm} . \mathrm{h}^{-1} \cdot \mathrm{ha}^{-1}$ na área estudada (BOIN, 2000), período de safra e plantio da cana-de-açúcar.

$\begin{array}{lllll}\text { Caminhos de Geografia } & \text { Uberlândia } & \text { v. 20, n. 72 } & \text { Dez/2019 } & \text { p. 55-77 }\end{array}$


Figura 10 - Formas erosivas em área de cultivo de cana-de-açúcar, subbacias SW e W.

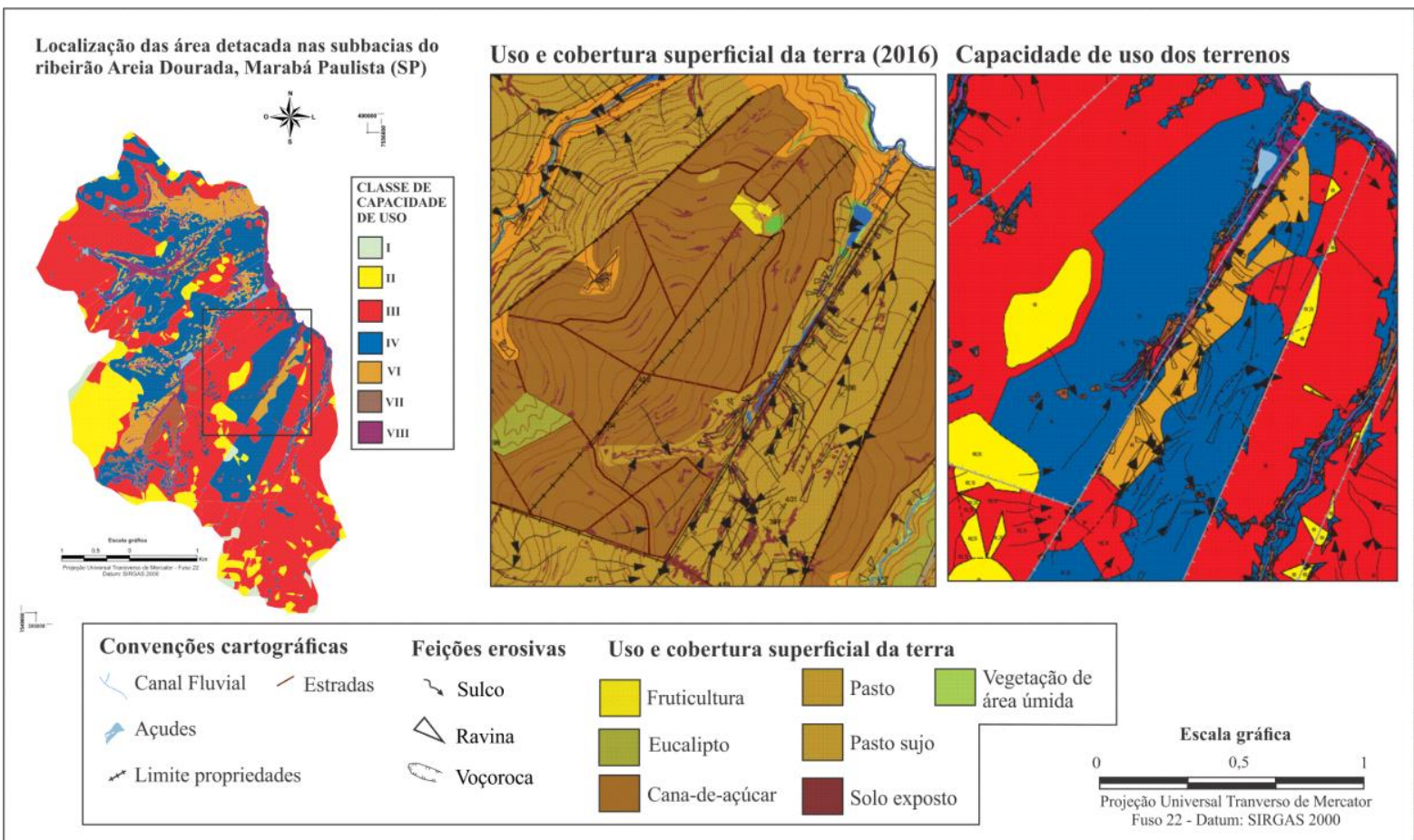

Outros terrenos na classe $\mathrm{VI}$, devido à presença de ravinas frequentes, encontraram-se nas baixas vertentes da subbacia $\mathrm{N}$. Nesse setor, o aumento do fluxo de água e sedimentos das vertentes para o fundo de vale proporcionou alterações na calha fluvial, de maneira a promover o solapamento das margens, observado in loco, e colapso da baixa vertente, de onde surgem diversas pequenas ravinas que tendem a erosão remontante (Figura 11). Esses terrenos também se encontraram sob pastagem, a qual reduziu a capacidade de uso da terra, sendo, portanto, inadequada nessas situações.

Figura 11 - Relações entre os sistemas vertente e fundo de vales, solapamento das margens e formação de ravinamentos na baixa vertente.

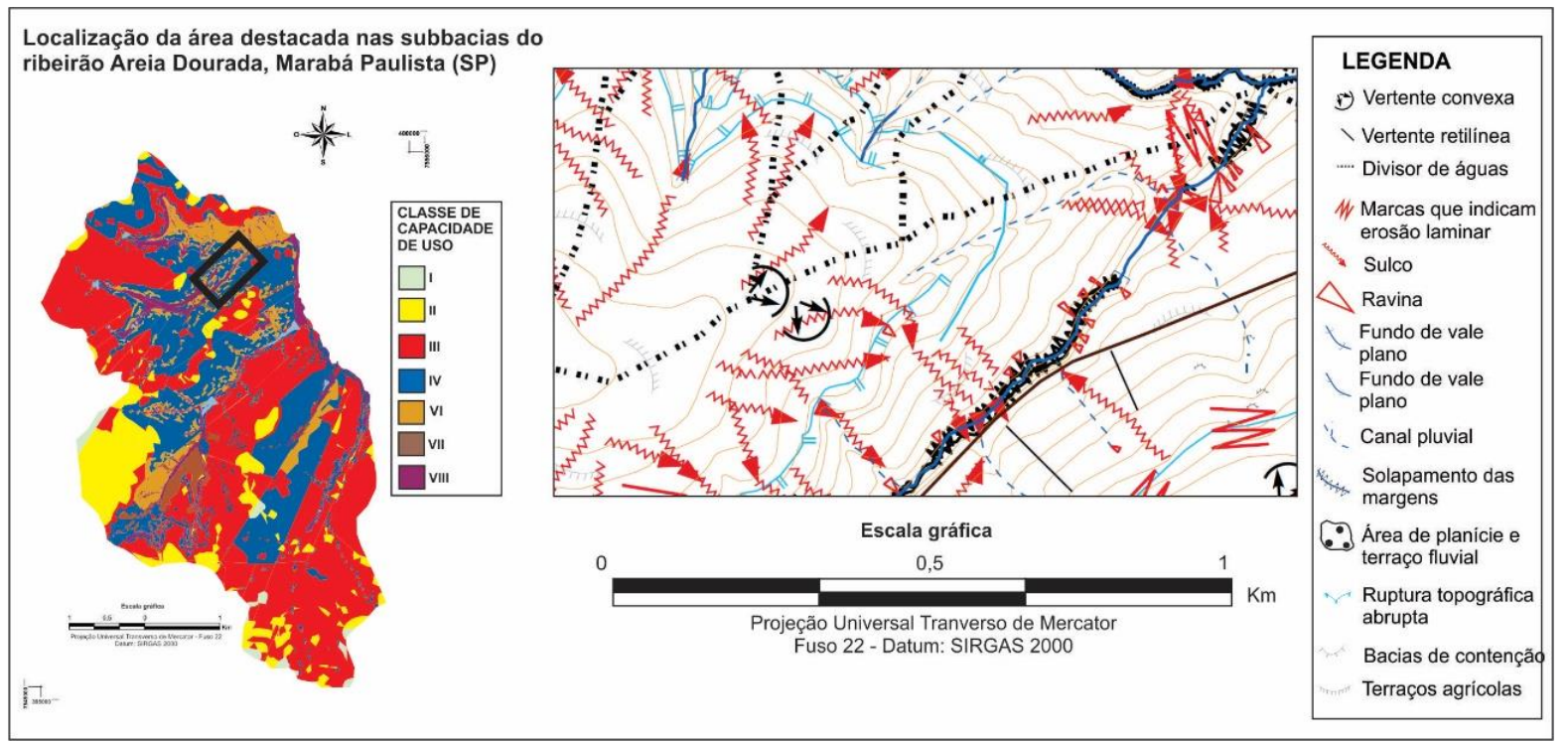


Em área próxima às rupturas topográficas com afloramentos de água, o uso para pastagem proporcionou o desencadeamento de distintos processos erosivos lineares e gravitacionais, formando sulcos, voçoroca e terracetes na classe III, em que, de acordo com a metodologia, tem-se a possibilidade de uso intensivo para pastoreio (Figura 12-1). Na subbacia W, atingida por expressivo processo de voçorocamento, na classe III e IV, os sulcos se desenvolvem conectados às ravinas e voçoroca a jusante, em terrenos da classe VI e VIII (Figura 12-2).

Figura 10 - Formação de sulcos, terracetes e voçorocas em terrenos da classe VI sob uso para pastagem, com terraços agrícolas. Fotografias retiradas por um veículo aéreo não tripulado (VANT).

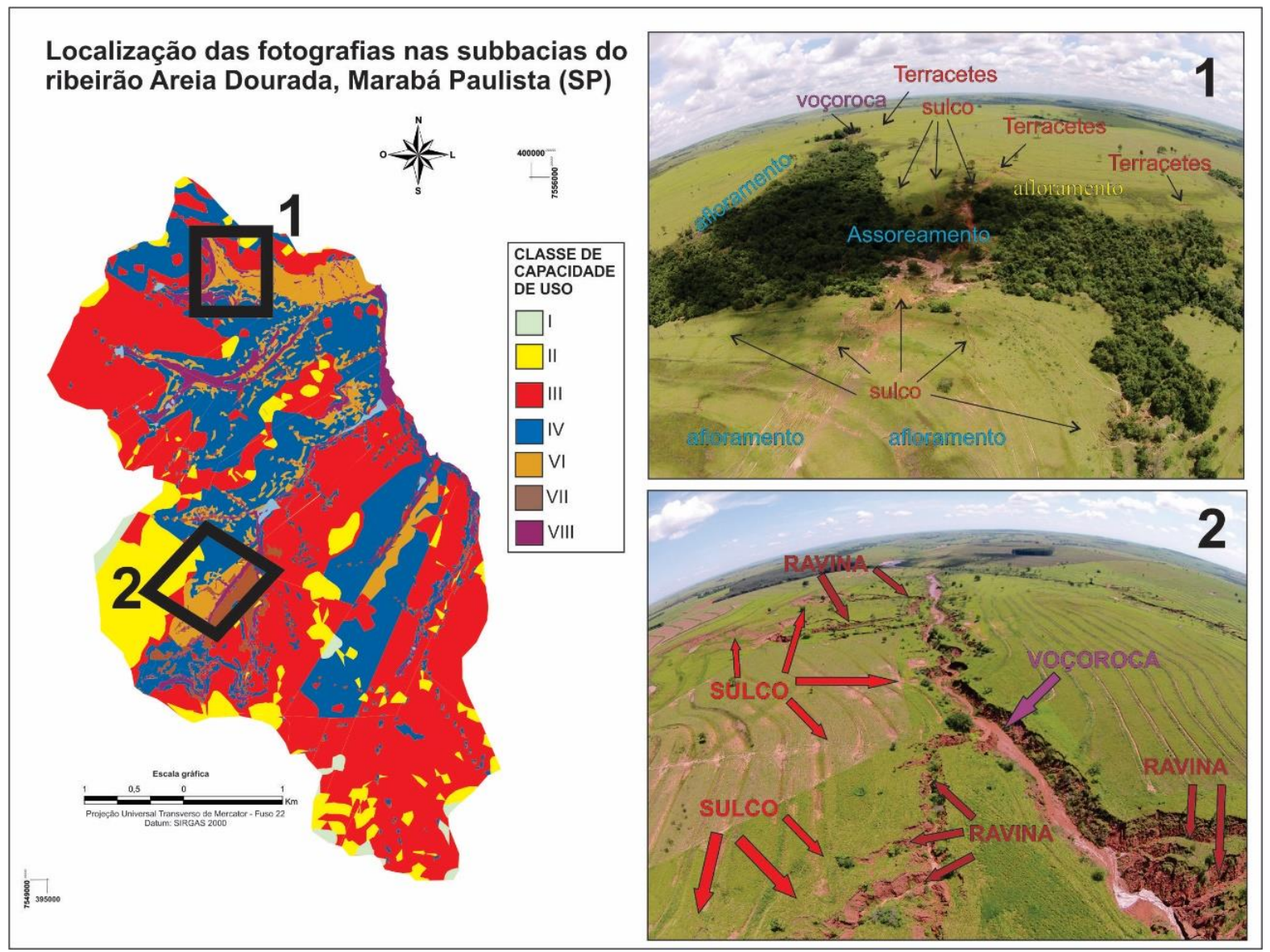

Nesses setores, em que a metodologia aponta para capacidade de uso intensivo para o pastoreio, verificou-se a intensa atividade erosiva, desde processos laminares, pelas manchas de solo exposto em meio as pastagens, lineares nos mais distintos níveis de desenvolvimento e gravitacionais, muitos dos quais proporcionados pelo uso intensivo dos terrenos para pastagens, mesmo quando da presença de terraços agrícolas, como pode-se observar nas fotografias da Figura 10.

Dessa forma, em sua maioria, exceto sobre terrenos na classe I em que se constatou na análise uso adequado e pela metodologia como subutilização, as pastagens proporcionam situações inadequadas, promovendo a erosão e a redução da capacidade de uso em todas as demais classes, enquanto a metodologia aponta a sobre utilização apenas quando da classe VIII.

Diferente dos demais trabalhos levantados, os quais utilizam a proposta metodológica de Lepsch (et al., 1983) para avaliar a sobre utilização das terras, as áreas a serem preservadas e o potencial de uso da terra, respectivamente em Cunha; Pinton (2012), Mendonça, et al. (2005) e Giboshi et al. (2005), neste trabalho buscou-se validar a metodologia. Para isso, associaram-se as classes de capacidade de uso com a problemática erosiva em sua perspectiva dinâmica, buscando identificar não apenas o potencial, como também as limitações da proposta frente às características da área e os problemas existente. 


\section{CONSIDERAÇÕES FINAIS}

A metodologia aplicada na área estudada apresentou-se limitada em termos preservacionistas, uma vez que com quatro processos de voçorocamento e outras centenas de feições erosivas em terracetes, ravinas e sulcos, além de áreas úmidas em setores de afloramentos de água na média vertente e áreas de terraços e planície fluvial, classificaram-se apenas $4,57 \%$ de todas as subbacias no grupo C, com capacidade apenas para vida silvestre, estando todo restante passível de algum tipo de uso agrícola. Dessa forma, constatou-se que a metodologia propõe um zoneamento da capacidade de uso extremamente permissivo frente a problemática erosiva encontrada na área estudada.

Neste estudo, verificaram-se diversas situações em que o uso e cobertura superficial da terra se encontram em condição de subutilização de acordo com a metodologia, mas, pela análise, apresentam intensa dinâmica dos processos erosivos e, consequentemente, reduzida capacidade de uso. Embora não se tenha avaliado a metodologia junto às técnicas conservacionistas adequadas, entende-se que essa proporciona significativa permissividade de uso da terra, enquanto o quadro ambiental da área suscita uma necessária intervenção preservacionista no entorno dos terrenos atingidos por voçorocamento e com afloramentos de água nas vertentes.

No caso das subbacias atingidas por processos de voçorocamento, quando analisada a dinâmica erosiva dessas áreas, verificou-se que os sulcos, ravinas e voçorocas encontraram-se conectados, de modo que o aumento de um proporcionou na evolução do outro. Ou seja, os terrenos mapeados no grupo A classe II, como aqueles com declive B $(2+5 \%)$ nos topos atingidos por sulcos, encontraram-se diretamente integrados aos terrenos em classes do grupo B e $\mathrm{C}$ atingidos por ravinas e voçorocas, em declive D (10+15\%), E (15+47\%) e F ( $\geq 47 \%)$, nas vertentes côncavas e fundos de vale. Nessas situações, onde registram-se voçorocas, a análise deve partir de toda bacia de contribuição, excedendo os limites das propriedades, de modo a avaliar as formas erosivas em conjunto, como um fenômeno sistêmico e não de maneira separada, fragmentada às propriedades, como propõe a metodologia.

Constatou-se também que a localização das classes limitadas aos fatores locais resulta na exclusão das áreas de transições entre as classes de menor para as de maior capacidade de uso. De acordo com Barros (2006), a importância desses setores de transição é reconhecida pela literatura desde os ecótonos trabalhados por Clements (1905). Outras denominações como bordas, quando no caso de áreas antropizadas (LOVEJOY et al., 1986), faixas de transição, fronteiras ou zonas de transição são utilizadas para esses terrenos.

A consideração dessas áreas de transição demonstrou-se de extrema importância na área estudada, ponderando toda a problemática erosiva apresentada. Entende-se que as condições dos terrenos do entorno de setores de maior predisposição a degradação possuem relação direta com a qualidade dessas áreas, do mesmo modo que a degradação desses terrenos afeta o seu entorno, como exemplificado nos terrenos atingidos por voçorocamento, nas baixas vertentes próximas aos canais com solapamento das margens e no entorno das rupturas topográficas com afloramento de água.

Além das considerações supramencionadas, ainda se avalia a importância de considerar as formas de relevo, com menor capacidade de uso em vertentes côncavas, indutoras de processos lineares. Para a área estudada também se faz pertinente considerar dados das litologias da Formação Adamantina para melhor compreender a hidrodinâmica do relevo, sobretudo pelos terrenos com rupturas topográficas e afloramentos de água nas médias e baixas vertentes.

Assim, para manutenção da pastagem na área estudada, compreendendo sua importância econômica para os proprietários, em todas as classes de capacidade de uso, mas sobretudo a partir da classe III, em que se registraram formas em estágio avançado do processo erosivo, é necessário, além de todas questões supramencionadas, de melhorias na estrutura dos solos, predominantemente arenosos e já muito desgastados pelo uso intenso e a visível necessidade de redução da quantidade de gado/ha.

Outrossim, o conjunto de medidas para culturas temporárias na classe II, no qual os autores colocam como necessário "[...] aração e plantio em contorno, plantas de cobertura, cultura em faixas, controle de água, proteção contra enxurradas advindas de glebas vizinhas, além de práticas comuns [...] como rotação de culturas e aplicações de corretivos e fertilizantes" (LEPSCH et al., 1983 p.42), proporciona o encarecimento do preço do cultivo, sendo necessário avaliar se esses procedimentos não inviabilizam a atividade nesse setor. 
Há uma nítida carência de ação pública no controle dos processos erosivos na área estudada, de elaboração de um zoneamento que adeque a pecuária às características físicas, aos solos predominantemente arenosos, desgastados pelo uso contínuo e pela dinâmica erosiva que estão submetidos.

Por fim, na questão da leitura cartográfica do produto final, a carta de capacidade de uso das terras, seguindo as orientações de Lepsch et al. (1983) no uso das cores, apresenta certas características que podem promover uma leitura equivocada do mapa. Ao utilizar do tom vermelho na classe de capacidade de uso III, promove em uma primeira leitura visual que nesses terrenos a problemática é superior à da classe IV, em azul, e da classe VI, em laranja, o que não condiz com o dado representado. Dessa forma, entende-se que o uso da rosa cromática, em que as cores mais fortes indicam a maior intensidade do fenômeno mapeado possibilitaria uma leitura mais adequada aos princípios da cartografia temática e, portanto, mais eficiente da carta.

\section{AGRADECIMENTOS}

À Fundação de Amparo à Pesquisa do estado de São Paulo (FAPESP) pelo fomento ao projeto de doutorado, processo 2015/ 00875-2.

À Marcel Nunes Ribeiro, Dr. Marcos Norberto Boin, Prof. Dr. João Osvaldo Nunes Rodrigues, Rodrigo Oliveira e Alexandre Gimenez pelas contribuições com a coleta das amostras em campo.

\section{REFERÊNCIAS}

BARROS, F. A. Efeito de borda em fragmentos de floresta montana, Nova Friburgo - RJ.

Dissertação (Mestrado em Ciência Ambiental). Universidade Federal Fluminense, Niterói (RJ). 2006. $100 f$.

BRASIL, Lei no 6938, de 31 de agosto de 1981. Dispões sobre a Política Nacional de Meio Ambiente, seus fins e mecanismos de formulação e aplicação, e dá outras previdências. Disponível em: <http://www.planalto.gov.br/ccivil 03/leis/l6938.htm>. Acesso em: 8 nov. 2016.

BRASIL, Constituição (1988). Constituição da República Federativa do Brasil: promulgada em 5 de outubro de 1988: atualizada até a Emenda Constitucional no91 de 18/02/2016. Disponível em: $<$ http://www.planalto.gov.br/ccivil 03/constituicao/constituicaocompilado.htm>. Acesso em 20 mai. 2017.

BRASIL, Lei no 4297, de 10 de julho de 2002. Regulamenta o art. 9o, inciso II, da Lei oㅜ 6938, de 31 de agosto de 1981, estabelecendo critérios para o Zoneamento Ecológico-Econômico do Brasil ZEE, e dá outras providências. Disponível em:

$<$ http://www.planalto.gov.br/ccivil 03/decreto/2002/d4297.htm>. Acesso em 20 mai. 2017.

BRASIL, Lei no 12.651, de 25 de maio de 2012. Dispõe sobre a proteção da vegetação nativa; altera as Leis $\mathrm{n}$ os 6.938, de 31 de agosto de 1981, 9.393, de 19 de dezembro de 1996, e 11.428, de 22 de dezembro de 2006; revoga as Leis nos 4.771, de 15 de setembro de 1965, e 7.754, de 14 de abril de 1989, e a Medida Provisória oㅡ 2.166-67, de 24 de agosto de 2001; e dá outras providências. [2012]. Disponível em: <http://www.planalto.gov.br/ccivil 03/ ato2011-2014/2012/lei/l12651.htm>. Acesso em: 8 nov. 2016.

BOIN, M. N. Chuvas e erosão no Oeste Paulista: uma análise climatológica aplicada. Tese (Doutorado em Geociências e Meio Ambiente), Universidade Estadual Paulista, Rio Claro, 2000. 264p.

CARVALHO, W. A. (Coord.). Levantamento semidetalhado dos solos da bacia do -SP. Presidente Prudente, São Paulo: FCT-UNESP, 1997.

CUNHA, C. M. L.; PINTON; L. G. Avaliação da capacidade de uso da terra da bacia do córrego do Cavalheiro - Analândia, SP. Geociência. v.31, n.3, p.459-471, 2012.

DE BIASI, M. A carta clinográfica: os métodos de representação e sua confecção. Revista do Departamento de Geografia, Universidade de São Paulo (USP), v.6, 1992, p.45-60. https://doi.org/10.7154/RDG.1992.0006.0004 
DEPARTAMENTO DE ÁGUAS E ENERGIA ELÉTRICA (DAEE); INSTITUTO DE PESQUISAS TECNOLÓGICAS. Controle de erosão: bases conceituais e técnicas; diretrizes para o planejamento urbano e regional; orientações para o controle de boçorocas urbanas. São Paulo: DAEE/IPT, 1989.

FERRARI LEITE, J. A ocupação do Pontal do Paranapanema. São Paulo: 1999.

FERREIRA, R.R.M.; FILO, J.T.; FERREIRA. V.M. Efeitos de sistemas de manejos de pastagens nas propriedades físicas do solo. Semina: Ciências Agrárias, Londrina, v.31, n.4, 2010, p.913-932. https://doi.org/10.5433/1679-0359.2010v31n4p913

FLORENZANO, T. G. Iniciação em sensoriamento remoto. São Paulo: Oficina de Textos, 2017. FOOKES, P.G.; LEE, E.M.; GRIFFITHES, J.S. Engineering geomorphology: theory and practice. Dunbeath: WhittlesPublishing, 2007.

GIBOSHI, M. L.; RODRIGUES, L. H. A.; LOMBARDI NETO, F. Sistema de suporte à decisão para recomendação de uso e manejo da terra. Revista Brasileira de Engenharia Agrícola e Ambiental. v.10, n.4, p.861-866; 2006. https://doi.org/10.1590/S1415-43662006000400012

GOVERNO DO ESTADO DE SÃO PAULO. Dispõe sobre o Zoneamento Ecológico Econômico do estado de São Paulo. Disponível em: <http://www.ambiente.sp.gov.br/cpla/zoneamento/zoneamentoecologico-economico/>;Acesso em: 05 de fevereiro de 2018.

INSTITUTO DE PESQUISAS TECNOLÓGICAS DO ESTADO DE SÃO PAULO (IPT, 1994). Orientações para controle de erosão na bacia do Rio Santo Anastácio - $3^{\mathrm{a}}$ fase, IPT. Relatório, №32.257, 1994, [s.n.].

INSTITUTO DE PESQUISAS TECNOLÓGICAS (IPT, 2012). Cadastramento de pontos de erosão e inundação no estado de São Paulo, Relatório Técnico № 131.057-205, [s.n.].

KARMAN, I. Ciclo da água: água subterrânea e sua ação geológica. In: TEIXEIRA, W.; TOLEDO, M.C.M.; FAIRCHILD, T.R.; TAIOLI, F. (org.). Decifrando a Terra. São Paulo. CompanhiaEditora Nacional, 2008. 557p.

LAL, R. Soil erosion in the tropics: principles and management. New York: McGraw - Hill, 1990.

LANE, M.The carrying capacity imperative: Assessing regional carrying capacity methodologies for sustainable land-use planning,Land Use Policy, v. 27, n. 4, p. 1038-1045, 2010.

https://doi.org/10.1016/j.landusepol.2010.01.006

LEPSCH, I. F.; BELINAZZI Jr., D.; ESPINDOLA, C. R. Manual para levantamento utilitário do meio físico e classificação das terras no sistema de capacidade de uso. $4^{\mathrm{a}}$ aproximação. Campinas: Sociedade Brasileira de Ciências do Solo, 1983.

MENDONÇA, I. F. C.; LOMBARDI NETO, F.; VIÉGAS, R. A. Classificação da capacidade de uso das terras na Microbacia do Riacho Una, Sapé, PB. Revista Brasileira de Engenharia Agrícola e Ambiental.v,10, n.4, p.888-895, 2005. https://doi.org/10.1590/S1415-43662006000400016

MONBEIG, P. Pioneiros e Fazendeiros de São Paulo. São Paulo: HUCITEC, 1984.

REDIN, M.; SANTOS, G.F.; MIGUEL, P.; DENEGA, G. L.; LUPATINI, M.; DONEDA; A; SOUZA, E. L. Impactos da queima sobre atributos químicos, físicos e biológicos do solo. Ciência Florestal. V.21, n.2, p.381-392, 2011. https://doi.org/10.5902/198050983243

SALOMÃO, F.X.T. Controle e prevenção dos processos erosivos. In: GUERRA, A.J.T.; SILVA, A.S.; BOTELHO, R.G.M. (Org.). Erosão e conservação dos solos: conceitos, temas e aplicações. $8^{a}$ edição. Rio de Janeiro: Bertrand Brasil, 2012.

SANTOS, R. F. Planejamento Ambiental: teoria e prática. São Paulo: Oficina de textos, 2004. 184p. SANTOS, R. D.; SANTOS, H. G.; KER, J. C.; ANJOS, L; H. C.; SHIMIZU, S. H. Manual de descrição e coleta de solo em campo. $7^{a}$ edição. Viçosa (MG) Sociedade Brasileira de Ciências do Solo, 2015. $100 \mathrm{p}$.

SOIL SURVEY STAFF. Soil Survey Manual. USDA: Soil Conservation Service, Agricultural Handbook. № 18, U. S. Gov. Print: Office, Wahsington, D. C. 1993. 
STEIN, D. P. Avaliação da degradação do meio físico. Bacia do rio Santo Anastácio Oeste paulista.Rio Claro, 1999. 197f. Tese (Doutorado em Geociências e Meio Ambiente), Universidade Estadual Paulista, Instituto de Geociências e Ciências Exatas, Rio Claro, 1999.

TRICART, J. Principesetméthodes de la géomorphologie.Paris: Masson, 1965, 496p. https://doi.org/10.1097/00010694-196510000-00015

ZANATTA, F. A. S.; LUPINACCI, C. M.; BOIN, M.N. O uso de anaglifos na identificação de feições erosivas: estudo de caso em área rural degradada. In: BOIN, M.N.; MARTINS, P. C. S.; MIRANTE, M. H. P. (Org.). Geotecnologias aplicadas às questões ambientais. Tupã (SP), ed. ANAP, $1^{\text {a }}$ ed., vol.1, 2017b, p.31-53.

ZANATTA, F.A.S.; LUPINACCI, C.M.; BOIN, M.N. Avaliação dos processos erosivos no Planalto Ocidental Paulista: um estudo de caso em busca das interações espaciais. Revista Brasileira de Geomorfologia. v.18, n.4, p. 767-782, 2017. https://doi.org/10.20502/rbg.v18i4.1029

ZANATTA, F. A. S. Limitação física em área rural degradada: busca metodológica para definir o uso adequado das terras. Rio Claro, 2018, 163p. Tese (Doutorado em Geografia - Organização do Espaço) Universidade Estadual Paulista, Instituto de Geociências e Ciências Exatas, Rio Claro, 2018.

Recebido em: 22/03/2018

Aceito para publicação em: 26/11/2019 